\title{
San Francisco Konferansı Sürecinde Büyük Devletlerin Veto Yetkisi Üzerine Tartışmalar
}

\author{
Mehtap BAŞARIR*
}

ÖZ

İkinci Dünya Savaşı'nın sonuna yaklaşılırken, bir savaşı kazanmak kadar yeni bir savaşı önlemenin zorluklarıyla hareket eden Müttefikler, savaşın galipleri olarak inisiyatifi ele almak üzere harekete geçmişlerdir. Böylece İkinci Dünya Savaşı'nın galipleri, savaş sonrası kurulacak uluslararası sistemi kendi istekleri ve mevcut güç ilişkileri kapsamında şekillendirmek üzere kolları sıvamıştır. Ne de olsa savaş sonrasının uluslararası düzenleri her zaman savaşın galipleri olan güçlü devletlerin istediği biçimde şekillenmektedir. Büyük güçlerin Mihveri yenilgiye uğrattıktan sonra istikbalde barış, istikrar ve kolektif emniyeti sağlamak adına yeni milletlerarası bir düzen kurma çalıșmaları Birleșmiș Milletler (BM) adını alacaktır. Bu çalıșma, Sam Francisco Konferansı döneminde büyük güçlerin, BM'nin barış ve güvenliğin korunmasındaki en önemli organı Güvenlik Konseyi'nde daimi üye pozisyonuyla veto hakkına sahip olmalarının Türk basınında nasıl değerlendirildiğini ele almaktadır. Bu konu kapsamında çalışmanın verilerini Milli Kütüphane'nin Süreli Yayın Arşivi'nden konuyla ilgili olarak taranan gazetelerin haber ve başmakaleleri, TBMM Zabıtları ve literatürdeki temel eserler oluşturmaktadır. Sonuçta anlaşılmaktadır ki, savaș sırasında üslendikleri görev ve sorumluluklarla orantılı nitelendirdikleri veto hakkına sahip bulunan büyük güçlerin bu yetkisi, Türk basını tarafından eksik ve kusurlu nitelendirilerek eleştirilmiştir. Açık biçimde hem TBMM kürsüsünde hem de basında yapılan eleştirilere rağmen uluslararası düzene ayak uydurarak bir teşkilat içerisinde bulunmayı tercih eden Türkiye, BM Teşkilatının bir üyesi olmayı kabul etmiştir.
\end{abstract}

Anahtar Kelimeler: Birleşmiş Milletler, Güvenlik Konseyi, Veto, Büyük Güçler

\section{Discussions on Veto Authority of Great States During the San Francisco Conference}

\begin{abstract}
As the end of the Second World War approaches, the Allies, driven by the difficulties of "preventing a new war" as well as winning a war, set out to take the initiative as the victors of the war. Thus, the victors of the Second World War rolled up their sleeves to shape the international system to be established after the war within the scope of their own desires and existing power relations. After all, the international orders of the post-war are always taking shape as desired by the powerful states that are the victors of the war. The efforts of the great powers to establish a new international order in order to ensure peace, stability and collective security in the future, after defeating the Axis, will be called the United Nations (UN). This study discusses how the "veto right of the great powers with their permanent member position in the Security Council -which is the most important organ of the UN in the protection of peace and security- is evaluated in the Turkish press, during the San Francisco Conference period. Within the scope of this subject, the data of the study consists of the news and editorials of the newspapers scanned from the Periodical Publication Archive of the National Library, the minutes and records of the Turkish Grand National Assembly and the main works in the literature. As a result, it is understood that this power of the great powers that have the right to veto - which they describe in proportion to the duties and responsibilities they assumed during the war - has been criticized by the Turkish press as deficient and imperfect. Turkey; Despite the criticisms made clearly both from the chair of the TBMM and in the press; chose to be in this organization by keeping up with the international order and accepted to be a member of the UN Organization.

Keywords: United Nations, Security Council, Veto, Great States.
\end{abstract}

\section{Giriş}

Birinci Dünya Savaşı'nın kitlesel yıkım getiren sonuçlarından sonra bir daha topyekûn savaşın tekrar etmemesi amacıyla Milletler Cemiyeti (MC) adıyla bir teşkilat kurulmuştur. MC'nin kuruluş amac1, uluslararası barış ve güvenliği saldırgan bir devlete veya devletler grubuna karşı kolektif bir hareketle sağlamaktı. Savaş karşıtı ve barış yanlısı gruplar, Birinci Dünya Savaşı'nın ortalarına doğru savaş sonrası kurulacak uluslararası örgütün yeni bir savaşı engelleyeceğini düşünüyorlardı (Barlas, 2017, s. 95). Bu teşkilatın doğuş kaynağı Amerikan Başkanı Wilson'du. Kurucu devletler, dünya barışını ilgilendiren her konuda MC’yi yetkili kılmışlar ve cemiyetin ulusların barışını etkin bir şekilde korumaya özgü önlemler almakla yükümlü olduğunu ifade etmişlerdir (Kutlu, 2018, s. 179). MC'nin örgütsel yap1sı, Genel Kurul (Meclis), Konsey ve Sekretaryadan oluşmuştur. Ayrıca Uluslararası Çalışma Örgütü (ILO), Uluslararası Sürekli Adalet Divanı ve MC Komisyonları da Sekretaryaya bağlıdır. MC’de yer alan Konsey, Genel Kurula

*Dr. Öğr. Üyesi., Kayseri Üniversitesi, mehtapbasarir@kayseri.edu.tr Makalenin Gönderim Tarihi: 05.03.2021; Makalenin Kabul Tarihi: 28.05.2021 
göre yetki ve görev dağılımı açısından önde bulunmaktadır. Oy birliği ile alınan kararlarda Konseyin, anlaşmazlıkları giderecek uzlaşma yolları bulmak; misakı ihlal eden MC üyelerinin cemiyetten uzaklaştırılması; manda devletlerin gözetim ve denetimi gibi görevleri vardı (Polat, 2020, s. 1955-1956). Anlaşılacağı üzere MC misakında oy birliği esası kabul edilmişti. Ancak MC'ye aza olan devletlerin arasındaki bir ihtilâfın çözümü için MC Konseyi’ne başvurulduğu zaman anlaşmazlık halindeki devletlerin oyları hesaba katılmadığından, bu kural çözüm noktasında yeterli gelmemiştir (Çubukgil, 1950, s. 174).

MC kolektif güvenlik ilkesi doğrultusunda, güçlüye karşı zayıfı korumayı hedeflerken kolektif güvenliği sağlama sorumluluğunu da önemli oranda büyük güçlere bırakmıştır. Üye devletler arasında çatışmaya yol açacak durumlarda MC, devletlerin öncelikle arabuluculuğa veya hukuki çözüm yoluna başvurmalarını önermektedir. Ancak her iki yoldan da bir çözüm elde edemeyen devletler Konseye soruşturma için başvurabilirdi. Hem arabuluculuk ve hukuki yollar hem de Konseyin soruşturmasından bir netice alınamazsa ve savaş kaçınılmazsa o zaman ancak üç ay sonra savaşa başlanabilirdi. Kısacası cemiyet sözleşmesi savaş1 yasaklamamış, ancak sözleşmeyi imzalamış olan ülkelerin, savaşa kalkışmadan önce tüm çözüm yollarını tüketmelerini zorunlu kilmıştır (Kıran, 2008, s. 26). Neticede kolektif güvenliğe duyulan inanç ve ihtiyaç iki savaş arası MC hareketine ilham verse de, MC'nin savaşı önlemekteki rolü kuruluşundan itibaren sınırlı kalmışır. Nitekim MC'nin kurucu devletlerinden İngiltere'nin Dışişleri Bakanllğı, savaşları önlemekten ziyade bazı savaşları geciktirebilecek bir mekanizmanın kurulmasını önermiştir (Barlas, 2017, s. 95, 96). Böylece cemiyetin temsil ve yaptırım kabiliyetinin etkin olmamas1 barışın sürdürülebilirliğini de olumlu katkı sunmamış dolayısıyla yeni bir kitlesel savaş İkinci Dünya Savaşı yaşanmıştır (Kutlu, 2018, s. 179).

İkinci bir genel savaşının engellenememesi MC'nin dünya barışını koruma amacında başarıya ulaşamadığının göstergesi olmuştur. MC tecrübesinden alınan derslerle 1945 yllında İkinci Dünya Savaşı'nın büyük yıkımı sonrasında uluslararası barış ve güvenliğin tesisi için inşa edilen Birleşmiş Milletler (BM), MC ile karşılaştırıldığında çok daha geniş bir zeminde tesis olunmuştur (Kutlu, 2018, s. 179). BM'nin hedefi bir daha herhangi milletin silaha başvurarak tecavüz siyasetini yürütmesine imkân vermemektir. Bu doğrultuda savaşta bütün güçlüklerle mücadele eden büyük güçler; barışa hizmet yolunda da işbirliği yaparak milletler arasındaki ihtilafları yok etmek ve hepsi arasında dostluğun hüküm sürmesini sağlamak amacindadır (Cumhuriyet, 26 Nisan 1945, s. 1).

Barış ve güvenliğin korunması işinden sorumlu bulunan büyük güçler, BM Teşkilatı içerisinde yer alan Güvenlik Konseyi'nde veto hakkına sahiptir. Veto hakkı adıyla şöhret kazanan hüküm belli başlı devletler arasında beraberliği sağlamak ve bu beraberlik olmadıkça barışın korunamayacağı düşüncesinden doğmuştur (TBMM Zabıt Ceridesi 7. Dönem, 19. Cilt, 90. Birleşim, 15.08.1945: 162). Bir bakıma büyük güçlere verilen istisnai durum (veto hakkı) savaş sırasında üstlendikleri özel yükümlülüklerden kaynaklanmıştır. Böylece Güvenlik Konseyi'nin üyelik kompozisyonunda, savaşı kazanan devletlerin daimi üyelikleri ve veto yetkileri dikkat çekmektedir. Konseyin inşa edilmesinde güç unsurunun ve mevcut güç dengesinin önemli bir bileşen olarak göz önüne alındığ1 görülmektedir. Dolayısıyla Güvenlik Konseyi kuruluşu itibari ile tüm devletlerin temsil edildiği demokratik bir platform olmaktan uzaktır (Gölçek, 2019, s. 467).

BM Teşkilâtı kurulurken bir hayli tartışılan oy meselesi (veto hakkı) hâlâ da birçok eleştirilere uğramaktadır. Büyük devletlerin oy meselesi Türk basınında da ciddi şekilde değerlendirmelere konu olmuştur. Özellikle basında, San Francisco Konferansı'nda temeli atılan BM Güvenlik Kurulu'nun yeryüzünde ahlak ve adalet prensiplerini hâkim kılacak erkte olup olmayacağı, bu harpten kuvvetli ve hazırlıklı çıkan BM Kurulu'nun etrafa saldırmak isteyenleri durdurup durduramayacağı ve BM Yasası'nın kendi menfaatlerini başkalarının hürriyet ve istiklalini feda ederek her aklına geleni yapmak isteyeceklere engel olacak tedbirleri alıp almayacağ gibi tartışmalar söz konusu olmuştur. Hâlihazırda tartışılan büyük güçlerin veto meselesi öncelikle Dumbarton Oaks ardından Yalta ve son olarak da San Francisco Konferansı'nda ele alınmışır. Biz de çalışmamızda bu kronolojik sıralamayı esas alarak veto meselesi üzerine tartışmaları ortaya koymaya çalışacağız.

\section{Oy Usulünün Dumbarton Oaks'ta Görüşülmesi}

San Francisco Konferansı çalısmalarına esas kabul edilen metin Amerika Birleşik Devletleri, Birleşik Krallık, Sovyet Rusya ve Çin Cumhuriyetleri tarafindan hazırlanan ve Dumbarton Oaks projesi adı ile 
anılan metindir (TBMM Zabıt Ceridesi, s. 156). Bir bakıma savaştan sonra kurulacak BM Teşkilatının esası, 1944 Dumbarton Oaks'dan beri hazırliğını sürdürmüştür (Sander, 2016, s. 194). Dumbarton Oaks Konferansı sırasında Güvenlik Konseyi’ndeki oy usulü üzerine birtakım tartışmalar yaşansa da milletlerarası sulhun bütün devletlerin eşitliği üzerine dayanabileceği fikri hâkim fikir biçiminde öne çıkmıştır (Çubukgil, 1950, s. 176, 177).

$\mathrm{Bu}$ noktada birtakım tezler öne sürülmüştür. Dumbarton Oaks projesinde ifadesini bulan ilk tez; silah kuvveti ve kaynak itibariyle savaşın önde gelen devletlerine milletlerarası barış ve güvenliğin korunmasında diğerlerine görece daha ağır bir mesuliyet ve mükellefiyet yüklemek, fakat bunun karşıllı̆ında onların oyuna diğerlerine nispeten daha üstün bir kıymet tanımaktır. İkinci tez ise; mesuliyet ve mükellefiyetlerde olduğu gibi alınacak kararlarda da tesir bakımından eşitliktir. Bu tez, hemen hemen bütün diğer milletlerce benimsenmiştir. Çünkü ikinci tez, devletlerin mutlak eşitliği ilkesinin yanı sıra demokrasi esaslarına da ilk teze nazaran daha uygun bir görüş olarak değerlendirilmiştir. ${ }^{1}$ Dünya barış ve güvenliğini korumak üzere gayret sarf eden büyükler ise mesuliyet ve kararda eşitlik ilkesine karşın; İkinci Dünya Savaşı'nı sadece kendi aralarında sağladıkları birlik sayesinde kazandıklarına dair görüşleri öne çıkarmışlardır (TBMM Zabıt Ceridesi, s. 158).

Konferans öncesi Dumbarton Oaks'da bir araya gelen büyük güçler oy meselesini ele almıştır. Sovyet Rusya kendi birliğini oluşturan her bağımsız cumhuriyetin oy sahibi olmasını talep ederken; Amerika ve İngiltere ise her devlete sadece bir oy hakk1 verilmesinde 1 srarc1 olmuştur. İngiltere ise sadece İngiliz imparatorluğunu teşkil eden dominyonların özel durumları göz önünde tutularak bunların birer oy sahibi olması lüzumunu ileri sürmüştür. Bunun yansıması olarak farklı taleplerle dünya teşkilatına katılacak devletlerin sahip olacakları oy hakkı meselesi Dumbarton Oaks'da bir karara bağlanamamış (Tasvir, 2 Nisan 1945, s. 1, 3) ve öncelikle Yalta Konferansı'na oradan da San Francisco Konferansı'na bırakılmıştır.

\section{Oy Usulünün Yalta'da Görüşülmesi ve Kabul Edilen Formül}

1945 Şubat ayında Yalta Konferansı'nda üç büyük devlet; Almanya'nın kayıtsız-şartsız teslim olmasına kadar savaşa devam edileceğine, devamlı bir barışın sağlanacağına, milletlerin yaşam seviyesinin yükseltileceğine ve hürriyetin bütün dünyaya yayılacağına dair amaçlarını ortaya koymuşlardır (Öztekin, 2016, s. 209). Çalışmamız açısından biz burada en önemli başlıklardan bir tanesi ortak barış sisteminin kurulmasına yönelik tartışmaları işleyeceğiz. Dumbarton Oaks tasarısında ele alınan Genel Kurul'da temsil ile Güvenlik Konseyi’nde oylama sorunları Yalta'da çözüme ulaştırılmış ve bu çözüm San Francisco Konferansı'nda da kabul edilmiştir.

Bağımsız devletlerin temsil edileceği Genel Kurul'da; Stalin on altı devletin temsilini talep etmiştir (Sovyetler Birliği on altı devletten kurulu bir siyasal birim olmakla birlikte, Sovyet Anayasası'na göre bu devletler bağımsız olup birliğe kendi istekleriyle katılmışlardı ve yine kendi istekleriyle bu birlikten ayrılabilecekti). Stalin'in bu isteğinin kabul görmesine karşın Roosevelt de “ABD kırk sekiz devletten oluşmaktadır" diyerek bu devletlerin de Genel Kurul'da temsilinin gerektiğini belirtmiştir (Sander, 2016, s. 195). Sonrasında ise Sovyet Rusya'nın Genel Kurul daimi azalığına Ukrayna ve Beyaz Rusya'nın da ayrı ayrı temsil edilmesi talebine karşın; hem ABD'nin hem de İngiltere'nin üçer oy sahibi olmak isteyebileceğine dair yorumlar Türk basınında eleştirel bakış açısıyla değerlendirilmiştir.

Büyük devletlerin Genel Kurul'da üçer oy sahibi olması durumuna değinen H. Cahit Yalçın'a göre, bu durum küçük- büyük her devletin hükümranlık hakkına bağlı kalınılacağı ve eşitlik ilkesinin uygulanacağ1 söylentilerini sözde bırakacağından dolayı (Tanin, 1 Nisan 1945, s. 1) demokrasinin savunucu Amerikan Başkanı Roosevelt'in dünyaya egemen kılmak istediği (dünyadaki tüm milletlerin bir arada barış ve müreffeh içinde yaşaması) hakikatle de çelişmektedir (Uşakligil, Son Posta, 1 Nisan 1945, s. 1). Neticede Sovyetler Birliği’nin yanında Ukrayna ve Beyaz Rusya’nın da Genel Kurul'da temsil edilmesiyle bir orta yol bulunmuş ve Sovyetler BM'de üç oy kazanmıştır (Sander, 2016, s. 195). Ayrıca Stalin, Roosevelt ve Churchill Yalta'da yaptıkları toplantıda Güvenlik Konseyi’ndeki oy usulünü de halletmişlerdir. Yalta

\footnotetext{
1 Birleșmiş Milletler teşkilatını vücuda getiren amaç doğrultusunda düşünüldüğünde bu tez zayıflamaktadır. Nitekim teşkilatı korumaktan maksat dünya barış ve güvenliğini korumaktır. Savaşın galipleri, savaş esnassında bir araya gelip zafere ulaşmaları üzerinden savaş sonrası barış ve güvenliğin korunmasında da kendilerine özel yükümlülükler düștügünü öne sürmüşlerdir. Bu özel yükümlülükler onlara oy konusunda olduğu gibi istisnai ayrıcalıklar yaratabilirdi.
} 
formülü diye anılan bu usul bu gün BM Antlaşması'nda aynen yer almıştır (Çubukgil, 1950, s. 176, 177). Daha önceki toplantılarda tartışmalara neden olan Güvenlik Konseyi'ndeki oylama sorunu; beş büyük devlete sürekli temsil ve "veto" yetkisinin verilmesiyle çözüme kavuşturulmuştur. ABD ile Sovyetler Birliği’nin yanında Çin, Fransa ve İngiltere "büyük devlet” kabul edilmiştir (Sander, 2016, s. 195).

Yalta oy formülü, Güvenlik Konseyi'nin, milletlerarası sulh ve güvenliğin devam ettirilmesi için sahip olduğu vazife ve mesuliyetleri iki grupta toplamaktadır. 8'inci bölüme göre Konsey; anlaşmazlıkların çözümlenmesi ile ilgili tedbirlerin alınması, anlaşmazlıklara yol açacak durumların düzeltilmesi, barışı tehdit eden vaziyetlerin tayini, bu vaziyetlerin giderilmesi gibi konularda karar alabilecektir. Bundan bașka bu tedbirlerin alınmasını gerektirmeyen kararlar da vermekle yükümlüdür. Yalta formülüne göre bu ikinci grup kararlar usul meselelerindeki oy usulü ile elde edilecektir. Birinci grup kararlar ise özel bir oy usulü ile - yedi nisabında büyüklerin ittifak şartı - elde edilecektir. Yalta oy formülü, Milletler Cemiyeti Konseyi'ndeki ittifak kaidesine karşı Güvenlik Konseyi’nde oylarda özel bir çoğunluk sistemi ortaya koymuştur. Bu sisteme göre Güvenlik Konseyi’nin süreli olmayan üyelerinin bir vetosu olmayacak; süreli üyeler için ise veto yetkisi devam edecektir (Çubukgil, 1950, s. 177-179). Konferansa sunulan tasarıya göre milletleraras1 teşkilatın ana hatları şöyledir: Teşkilat dört organ üzerine kurulacaktır (Sertel, Tan, 25 Nisan 1945, s. 1, 2):

i. Güvenlik Konseyi: Barışın korunması sorumluluğu bu konseye ait olacaktır. Güvenlik Konseyi 11 üyeden oluşacaktır. İngiltere, Amerika, Sovyet Rusya ve Çin, sonra dâhil edilen Fransa'da bu konseyin daimi üyesi olacak, geri kalan üyelikler de diğer devletlerden nöbetleşe seçilecektir. Oylar yedi üyenin çoğunluğuyla verilecektir. Yalnız beş büyük devletin mutlaka oylamaya katılımı gereklidir. Güvenlik Konseyi daimi surette toplantı halinde bulunacaktır. ${ }^{2}$

ii. Genel Meclis: Milletlerarası teşkilata girmiş bulunan bütün ülkelerin temsilcilerinden oluşacaktır. Burada küçük büyük bütün milletler eşit oy sahibi olacaklardır. Genel Meclisin vazifesi barışın korunmasından başka bütün milletlerarası meselelerle meşgul olmaktır.

iii. İçtimai ve İktisadi Komiteler: Genel Meclis tarafindan seçilmek ve Genel Meclis'e karşı mesul olmak üzere biri içtimai diğeri iktisadi iki komite kurulacaktır. Bu komiteler Genel Meclis kararlarının uygulanması, milletlerarası içtimai ve iktisadi işbirliğinin düzenlenmesi ve organizasyonu ile meşgul olacaklardır. Ayrıca bütün ülkelerde insan haklarının korunmasına nezaret edeceklerdir.

iv. Adalet Divanı: Milleler arasındaki hukuki ihtilafları barış yoluyla çözmek için Genel Meclis'e bağlı bir Adalet Divanı kurulacaktır. Milletler aralarındaki ihtilafları barış yoluyla halledemedikleri takdirde Adalet Divanı'na başvurmaya mecbur olacaklardır. Adalet Divanı'nın kararlarına uymayanlar hakkında Güvenlik Konseyi yaptırım tedbirleri alacaktır.

BM Teşkilatının yukarıdaki yapısı göz önüne alındığında büyük ve küçük devlet arasındaki eşitsizlik meselesi ilk olarak idare meclisinde sürekli veya geçici üye olmak noktasında belirmektedir. İkinci eşitsizlik ise sürekli üyelere tanınan veto yetkisidir. Böylece sürekli ve geçici iki çeşit üyeden meydana gelen idare meclisi, konuşma masasına getirilen her meseleyi oy çoğunluğu ile karara bağlarken, büyük devletlerden biri küçük devletlerden biriyle karşı karşıya geldiği zaman oy çoğunluğu yerine oy birliğine ihtiyaç duyulacak olmasıdır (Uşaklıgil, Son Posta,1 Nisan 1945, s. 1).

Yalta'da değerlendirilen Dumbarton Oaks tasarısında ileri sürülen milletlerarası teşkilatın en önemli organı; saldırıya engel olmak gerektiğinde kuvvete başvurmak hak ve salahiyetine sahip Güvenlik Konseyi'dir. Güvenlik Konseyi daha harp tehlikesi başlamadan barışı tehdit eden etkenleri ortadan kaldırmak yetkisine dahi sahip olacaktır. Böylece Güvenlik Konseyi’nin kararı üzerine bütün devletler yaptırım tedbirine başvurmaya mecbur tutulacaktır (Sertel, Tan, 25 Nisan 1945, s. 1, 2). Anlaşılacağı üzere Güvenlik Konseyi hem güvenlik hem de barışı korumakla yükümlü en güçlü organdır. Güvenlik Konseyi'nin aldığı kararlar, tüm üye ülkeler açısından bağlayıcılık taşımaktadır.

\footnotetext{
${ }^{2}$ Coğrafi temsil doğrultusunda yetersiz bir görüntü sunan Güvenlik Konseyi’nin üyelik bileşimi coğrafi kıstasa göre orantısızdır. BM’nin kurulduğunda 51 üyesi varken bugün üye sayısı 193'e ulaşmışır. Üyelik sayısında yaklaşık dört katlık bir artış söz konusu iken Güvenlik Konseyinin üyelerinin coğrafi dağllımlarında herhangi bir değişikliğe gidilmemiştir. Sadece 1965 ’te yürürlüğe giren değişiklik ile başlangıçta 11 üye ile kurulan Güvenlik Konseyinin üyelerinin sayısı 15'e yükseltilmiştir. Bu değişikliğin ardında sömürgeciliğin sonlandırılmasıyla çok sayıda Afrika devletinin bağımsız olması yatmaktadır. Ancak bu değişiklik ciddi bir düzenleme sağlamazken bu tarihten sonra da yeni bir düzenlemeye gidilmemiştir (Gölçek, 2019, s. 468).
} 
Yalta'da bir araya gelen büyük güçler, neticede San Francisco Konferans1 toplanmadan önce Dumbarton Oaks önerilerinin belirli ve özellikle de veto ile ilgili eleştirilen hükümlerine rağmen uluslararası bir örgütün kurulması lehinde genel bir anlaşmaya varmışlardır (HC (House of Commons) Deb (Debate) 22 August 1945 (The Full Date) vol (volume) 413 c. (Column) 659). Armaoğlu, Yalta Konferansı hakkında şu yorumu yapmıştır: "Burada bahis konusu olan veto ve üyelik meselesiydi. Güvenlik Konseyinin devamlı üyeleri için veto ilkesi kabul edildi” (2016, s. 361).

Kısacası Yalta formülüne göre, esasa ilişkin kararlar, süreli üyelerin ittifakı - iki süreli olmayan üyenin olumlu oyuyla alınacaktır. Çubukgil'e göre, süreli üyelerin sorumlulukları göz önüne alındığında; milletlerarası barış ve emniyetin esasına ait önemli bir meselede, üzerlerine alacakları vecibe dolayısıyla katılmadıkları bir kararın neticelerini yüklenmeleri de beklenemez. Bir bakıma İkinci Dünya Savaşı'nın büyük devletlerin müşterek işbirliği ile kazanılması barışın devamı için de sadece büyük devletlerin birliğini ve teşkilatlanmasını ön plana taşımışıı (1950, s. 179, 180).

\section{Oy Usulünün Yalta'da Görüşülmesi ve Kabul Edilen Formül Üzerine Tartışmalar}

San Francisco Konferansı öncesinde Yalta formülü biçiminde isimlendirilen ve BM içerisinde yer alan Güvenlik Konseyi'nin güvenlik ve barışı korumak adına büyük güçlere tanıdığı veto hakkı tartışma konusu olmuştur. Hatta bu mesele üzerinden büyük güçler arasında yaşanılan tartışmalar nedeniyle planlanan San Francisco Konferansı'nın başlamadan biteceğine dair yorumlar dahi yapılmıştır (Sertel, Tan, 6 Nisan 1945, s. 1; Nadi, Cumhuriyet, 3 Nisan 1943, s. 1, 3). Büyük devletlerin her şeye rağmen bir şeyler yapmak üzere harekete geçmelerini olumlu değerlendiren Ulus gazetesi yazarı Atay, iyi niyetlerle oluşturulan bir teşkilatın zaman içerisinde her türlü kusurdan arındırılabileceğini savunmakta, aksi takdirde hem büyük hem de küçük ülkelerin durmadan silahlanacağını öne çıkarmaktadır. Bu nedenle Atay, eşit egemenlik hakkının uygulanmasıyla dünya nüfusunun en büyük kısmını oluşturan ve barış kararında birleşen ortanca ve küçük devletlerin bu isteğinden faydalanmak ve onları gerçekten ve isteyerek katılacakları bir teşkilatlanma içinde harp aleyhine ve barış lehine çalıştırmak fırsatının kaçırılmamasını tavsiye etmektedir (Ulus, 2 Nisan 1945, s. 1, 3). Çünkü Sovyet Rus âleminin dünyanın diğer milletleriyle kuracağı ilişkiler eğer demokrasi ruhunun gereklerine uydurulamaz ve iki taraf arasındaki karşıllklı saygı ve tolerans kurulamazsa dünyanın ümitleri boşa çıkacak, dolayısıyla insanlık huzura ve emniyete kavuşamayacaktır. Bundan dolayı Yalman'a göre, San Francisco'da toplanacak olan konferansın hedefi, bu harpte aynı tarafı tutan ve aynı davayı güden milletler arasında tam manasıyla barış ve anlaşma kurmaktır. Ancak bütün bir geçmişi dolduran menfaat ve görüş farklılıklarının, kuruntuların, şüphelerin bir hamlede ortadan kaldırılamayacağının farkında bulunan Yalman, daha konferans kapısına varılmadan birtakım gürültülerin kopmasını olağan değerlendirmektedir (Vatan, 3 Nisan 1945, s. 1, 3).

Tan gazetesi yazarı M. Zekeriya Sertel kaleme aldığı makalesinde Müttefikler arasında ufak tefek görüş farklarını bir ayrılık başlangıcı gibi yorumlayan basın yazarlarını eleştirmektedir. Müttefikler arasındaki ihtilaflara ait haberlerin iç yüzü hatta esası anlaşılmadan nedense en çok Türk gazetelerini ilgilendirmesini ve bu noktada başmakaleler kaleme alınmasını eleştiren Sertel'e göre bu durum, başyazarların içindeki temennileri dışarı aksetmesinden ibaret psikolojik bir meseledir. Türk basınındaki genel kanaatin; Müttefikler arasında büyük menfaat, ideoloji ve görüş zitlığının er geç bir anlaşmazlığa sebebiyet vermesi üzerine inşa edildiğine dikkat çeken Sertel, gazetelerdeki bütün değerlendirmelerin hep bu görüsslere dayandırıldığını söylemektedir. İlaveten Türk basınında, Rusya ile Müttefikler arasında San Francisco Konferansı’nda kullanılacak oy sayısı üzerinde bir anlaşmazlık bulunduğu dedikodularının adeta Müttefikler arasında bir ayrılık başlangıcı gibi yorumlanmasını da eleştirmektedir (Tan, 4 Nisan 1945, s. 1, 2).

San Francisco'da toplanacak konferansın ertelenip ertelenmeyeceği gündemdeyken Sovyet Rusya'da yayınlanan Pravda gazetesi San Francisco Konferansı'nın tam zamanında toplanacağını ve vazifesini yerine getireceğini söylemiştir. Aynı zamanda gazete, Rusya, Amerika ve İngiltere arasında tüm zorluklarda olduğu gibi zaferlerde de mevcut bulunan bağ sayesinde sağlam ve devamlı bir barışın oluşturulacağını öne çıkarmıştır. (Vatan, 5 Nisan 1945, s. 1, 3). Anlaşılacağı üzere üzerinde tartışmaların olduğu BM konferansının ertelenmesi için bir durum söz konusu değildir. Ertelenmesi mümkün görülmeyen San 
Francisco Konferansı'nda barış ve emniyete giden yol ise Yalman'ın değerlendirmesiyle Müttefikler arasındaki karşılıklı anlayış ve saygiyla elde edilecektir (Vatan, 6 Nisan 1945, s. 1).

Türk basını, sağlam bir barış oluşması için üç büyüklerin kendi aralarında anlaşabilmelerini öne çıarırken; Güney Afrika Başbakanı Mareşal Smuts da konferansa katılacak küçük devletlerin bazı fedakârlıklara katlanmaları gerektiğini söylemiştir. Sağlam bir barış kurulabilmesi için bunun gerekli olduğunu belirten Smuts, aksi halde üçüncü bir dünya harbinin önüne geçilemeyeceğini sözlerine ekleyerek: "Üçüncü bir dünya harbi insanlığın mahvolması demektir" (İkdam, 6 Nisan 1945, s. 1) demiştir.

Amerikan Dışişleri Bakanı Stettinius küçük milletleri rahatlatmak üzere, Yalta Konferansı'na katılan Amerika'nın, küçük milletlerin meşru haklarına saygı gösterme hususunda kesin kararını gösterdiğini söylemiştir. Küçük memleketlerin istiklaline ve kendi işlerini kendilerinin halletmek haklarına dünyada hiçbir milletin Amerika'nın gösterdiği alakadan daha büyük bir alaka göstermediğini belirten Stettinius, Dumbarton Oaks tekliflerinin esasının da bu olduğunu belirtmiştir. Stettinius’a göre, küçük milletlerin hürriyeti ve istiklali ancak büyük devletlerin, eşitliğe sayg1 göstermesiyle ve barışı korumak adına kuvvetlerini birleştirmesiyle sağlanacaktır. Stettinius ancak bu şekilde, hem küçük, hem büyük memleketlerin tek ümidi barış için teşkilatlandırılmış bir dünyanın kurulacağını öne çıkarmaktadır (Vatan, 9 Nisan 1945, s. 1, 3).

Stettinius'un yukarıdaki açıklamalarından sonra BM teşkilatının yapısı üzerinde Türk basınında bir de küçük-büyük devlet tartşsması söz konusu olmuştur. Buna göre, Stettinius’ün ortaya attı̆̆ küçük- büyük devlet tartışmasına hukuki yönden yaklaşan M. Faik Fenik'e göre, devlet kavramının hukuka göre tek anlamı, devletin yalnız hür ve bağımsız bir varlık olmasıdır. O halde her türlü ayırmanın dışında devletin her yerde ve her zaman bir bütün olarak ele alınması gerektiğini söyleyen Fenik'e göre: küçük veya büyük olan "devlet" değil belki toprak ve nüfuz göz önüne alınarak doğrudan doğruya "memlekettir". Böylece devlet teriminin hukukun; memleketin de coğrafyanın içine girdiğini belirten Fenik, küçük devlet olamayacağı gibi küçük milletin de olamayacağına açıklık getirmiştir. Ne devletin ne de milletin böyle bir şeye karıştırlmamasını belirten Fenik, küçük devlet denildiği zaman arazisi küçük, nüfusu az fakat hür ve bağımsız devletlerin kastedildiğini anlamanın yerinde ve akıllıca bir hareket olduğunu öne çıkarmaktadır. Böylece küçük devletlerin hakları diye ortaya atılan bir mevzunun her devletin hukukuna ait bir şey olduğunu kabul etmenin ve böylelikle doğrudan doğruya bütün hür ve bağımsız devletlerin aynı ve eşit haklara sahip bulunduğunu tanımanın yerinde olduğunu söyleyen Fenik, bu düşüncesini Amerikan Dışişleri Bakanı Stettinius'un görüşüyle desteklemektedir. Yeni dünya düzeni için Amerikan görüşünü anlatan Stettinius'in, küçük devletlerin de hak ve hürriyetine saygı duyulacağını söylemesinden kastettiği mananın, az toprak ve az nüfus sahibi olan devletler olduğunu tahmin etmenin zor bir şey olmadığına değinen Fenik, zaten bu harbin amacının da küçük memleketlerin hak ve hürriyetlerini korumak, onların başkalarının köleliği altına girmelerini önlemek olduğunun altını çizmiştir. Aksini düşünmenin demokrasiyi sözde bırakacağını söyleyen Fenik'e göre, bu savaştan sonra insanlar hür ve hukukça eşit biçimde doğacakları gibi devletler de hür ve hukukça eşit olarak yaşayacaklardır. Böylece yazar, Müttefiklerin demokrasi zaferinin harp sonrasında bu ülküyü gerçekleştireceğini öne sürmüştür (Ulus, 12 Nisan 1945, s. 1, 2).

San Francisco Konferansı öncesinde, sağlam ve sürekli bir barış kurabilmesi için devletler arasında küçük- büyük farkı gözetmeksizin her millete eşit haklar, hürriyetler ve ödevler tanıyan ideal bir düzen yaratılması gerektiğine dair fikirler ileri sürülmüsstür. Ancak bir devletin büyüklüğünü öne çıkaran ölçünün yaşanılan süreçte savaş potansiyeli olduğunu söyleyen Nadir Nadi’ye göre, yarının barış düzeni de hukukçular arasındaki kuramsal tartışmalardan ziyade müşterek milli dövüş gücüyle birbirine yaklaşan devletlerin görüş birliği üzerine kurulacaktır. Bu durumda büyük güçlerin, büyük küçük her milletin istiklalini, toprak bütünlügünü, bütün hukukunu koruyarak, saldırıyı ve savaşı engelleyerek ve milletlerarası anlaşmazlıkları barış yoluyla çözerek ileri bir dünyanın temelinin atılabileceğini belirtmektedir (Cumhuriyet, 12 Nisan 1945, s. 1). İkdam gazetesinde çıkan imzasız başmakalede Nadi'yi destekleyerek, büyük güçlerin, barışın emniyetini her milletin menfaat ve bağımsızlığına en uygun bir tarzda tespit ve formüle edebilmeleri neticesinde devaml bir sulhun elde edileceğini ortaya koymuştur. Neticede gazete, Müttefiklerin er geç kendi menfaat ve görüş açısından gelecek planını düşünmeden, infirada ve inada sapmadan, ortak bir dünya görüşü esası üzerinde uzlaşmaya varmak zorunda kalacağını böylece de adaletli sürekli bir barışın oluşturulabileceğini ümit etmektedir (İkdam, 10 Nisan 1945, s. 1). 
Türkiye'nin de katılacağı San Francisco Konferansı'nın içeriğine açıklık getiren Amerikan Dışişleri Bakanı Stettinius, bu konferansın, sadece sulhu korumak için dünya teşkilatına ait bir anayasa hazırlayacağını ve bu yasanın da onaylanmak üzere BM'ye bırakılacağını belirtmiştir (Vatan, 9 Nisan 1945, s. 1, 3). Stetinius'un da öne çıkardığ gibi San Francisco Konferansı'nda barışı emniyet ve güvenilir nizamlar altında tutabilmenin imkân ve tedbirleri belirlenecektir.

San Francisco Konferansı öncesinde meydana gelen en önemli gelişme Amerikan Cumhurbaşkanı Roosevelt'in 12 Nisan'da hayatını kaybetmesidir. Roosevelt'in ölümünden sonra yeni Birleşik Amerika Cumhurbaşkanı Harry Truman ant içerek görevine başlamıştır. Başkan, selefinin siyasetine sadık kalacağını beyan etmiş ve kabineye vazifesine devam etmesini söyleyerek, San Francisco Konferansı'nın belirlenen tarihte toplanması için Dışişleri Bakanı Stettinius'a talimat vermiştir (Akşam, 13 Nisan 1945, s. 1). Şahsen Rossevelt'e ait olan San Francisco'da bir konferans toplanması düşüncesi, Yalta'da Stalin ve Churchill tarafindan da kabul görmüştür. Roosevelt’in amac1, mevcut savaşı sulha ulaştıracak antlaşmadan ziyade gelecekte herhangi yeni bir muharebeye yer bırakmayacak barış teşkilatı kurmaktı. Yeni Amerikan Başkanı Truman da selefinin bütün isteklerini yerine getirmeyi açıkça üstlendiğinden dolayı daimi barış teşkilatının kurulması işi büyük bir hızla ve Roosevelt’in artık vasiyet niteliğini alan irşat ve işareti ile devam etmiştir (Yeni Sabah, 16 Nisan 1945, s. 1). Ayrıca köklü bir barışın sağlanması adına Truman, San Francisco misakına hâkim ruhtan şöyle bahsetmiştir: Hiçbir millet başka bir milletin zararına hareket edemeyecektir, dünyaya hâkim olmaya kimsenin hakkı yoktur, barış için herkesin ödeyeceği kiymet budur.” Truman bu nutku ile Amerika'nın bağımsız bir dünya adına haklı, emniyetli ve sürekli bir barış ve onun teminatı üzerinde 1srar edecek bir hareket tavrını muhafaza ettiğini sergilemiştir (Benice, Son Telgraf, 22 Haziran 1945, s. 1). Böylece Benice barıştan yana bir dünyanın doğması adına Dumbarton Oaks ve San Francisco Konferansı'nın önemli arayış eserleri olduğuna da dikkat çekmektedir. Neticede dünyanın genel barışını her millete güvenli ve adaletli bir hale getirebilmek ve hiçbir özel ve karşıllkklı özel emniyet tedbirlerine gerek kalmadan dünyanın ileri emniyetini genel bir sistem içinde sağlamak yazara göre ideal olan düşünce sisteminin ifadesidir (Son Telgraf, 24 Nisan 1945, s. 1, 3). Böylece yazar, yeryüzünün güvenli ve emniyetli bir barışa kavuşabileceğini belirtmektedir.

İkinci Dünya Savaşı'nın sonu için ümitli bulunmaktan vazgeçilmemesini söyleyen Kemal Turan ise, barışı isteyen herkesin aynı zamanda Türkiye'nin de bunun için emek harcaması gerektiğini yaşanılan sürecin parolası biçiminde şöyle öne çıarmıştır: "Hiçbir millete karş1 gizli niyeti ve ihtilaflı meselesi olmayan Türkiye Cumhuriyeti milletçe maddi ve manevi alanlarda ilerleme gayretleriyle milletler ailesi içinde dostluk ve iyi geçinme münasebetleriyle bir sulh ve istikrar unsuru olarak yaşamak azmindedir." Kısacası Turan, bütün dünya ile birlikte Türkiye'nin de dikkatini San Francisco Konferansı'na ve emeklerini de yurdun refahına çevirdiğini söylemiştir. Böylece yazara göre, çalışmanın ve emeğin, barışa kavuşma arzusu ne kadar şiddetli olursa, insanlığın kendine yaraşan büyük bir güvenlik âlemine kavuşması da o derece köklü olacaktır (Ulus, 22 Nisan 1945, s. 1, 3).

Ancak Akşam'da yazan Sadak, Turan'dan farklı olarak emek harcayan Müttefiklerin barışı sağlayabileceklerine şüpheyle yaklaşmaktadır. Sadak bu makalesinde genel itibariyle veto meselesinin dünya barışı üzerinde açtığı yara üzerinde durmaktadır. Siyasetçilerin, "harp sırasında üç büyük devletin cephelerde işbirliği sağlaması zaferi sağladıysa harpten sonra da sürekli işbirliği, her sahada uzlaşma ve beraberlik barışı sağlayacaktır" biçimindeki yorumları, Sadak’a göre ancak bir hayaldir. Çünkü yazara göre birlik ve beraberliğin devam etmesi için Avrupa'da da, Amerika Birleşik Devletleri veya İsviçre Kantonları gibi toplu veya tek parça bir devlet kurulması gerekirken; Avrupa'da devam eden menfaat sürtüşmesi çerçevesinde nüfuz bölgeleri oluşturulmaya çalışılmaktadır. Bunun dışında Sadak'a göre siyasetleri, menfaatleri, insanların ve milletlerin hayatı hakkında görüş ve düşünüşleri, tarih ve coğrafyaları dahi ayrı olan bu üç devletin barışı korumak adına sürekli birlik içinde kalacaklarına güvenmek sadece çocukluktur. Savaş sonunda barışı ve güvenliği korumak için sadece üç devlet arasındaki birliğin yetmeyeceği düşüncesiyle milletlerarası bir kurul hazırlandığına dikkat çeken Sadak, kurulacak emniyet teşkilatının, üç devlet işbirliğinden bağımsız olarak harekete geçmesinin yani herhangi bir saldırı karşısında otomatik şekilde işlemesi gerektiğini söylemektedir. Nitekim savaş sonunda herkesin niyet ve hedeflerinin belli olmamasından kaynaklı, birbirlerinden çekinen büyük devletlerin yarınki barış ve güvenliği hem kendi aralarındaki anlaşma ve işbirliğine hem de milletlerarası geniş bir kurula bağlamak yolunu tuttuklarını dile 
getiren Sadak, bundan dolayı yeni projede, dünyanın en büyük garabetine düşmelerini meşhur oy meselesine şu şekilde dayandırmaktadır:

"Bilindiği gibi yeni kurulun konseyinde yani idare meclisinde 11 devlet bulunacaktır. Bunlardan beşi (Amerika, İngiltere, Sovyet Rusya, Çin, Fransa) hiç değişmeyen sürekli üyelerdir. Geri kalan altı üye, diğer devletler arasından iki yılda bir değişmek üzere seçilir. Barışı ve güvenliği bozan, işgale kalkışan bir devlet hakkında zorlayıcı tedbirlere, askeri harekete ancak bu konsey karar verebilecek. Fakat konseyin çoğunlukla vereceği bu kararlarda beş büyük devletin ittifakı şarttır. Demek oluyor ki büyük devletlerden biri başka bir ülkeyi işgale kalkışırsa ona karşı hiçbir tedbir alınmayacaktır. Çünkü kararda bu devletin kendi oyu şarttır. İşgaller ve savaşlar hep büyük denilen devletlerden çıktığına göre yeni kurulacak teşkilat işgale asla engel olamayacaktır. O halde milletlerarası kurul bu kadar zahmet ve didişme ile kime hazırlanıyor? Bir küçük devlet bir büyük devlete veya bir başka küçüğe saldırırsa o zaman konsey harekete geçecek zorlayıc1 tedbirlere hatta o ülkeye karşı hava kuvvetleri ve ordular göndermeye karar verebilecektir. Fakat küçük devletin arkasında bir büyük devlet varsa bu kez büyük devletin konseyde veto hakkı olacağı için saldırgan küçük devlete karşı zorlayıcı tedbirler söz konusu olmayacaktır. Oy meselesi bu şekliyle kalırsa dünya barış ve güvenliği pamuk ipliğine bile bağlanamaz. Bu nedenle milletlerarası güvenlik kurulu, her türlü saldırıya karşı, saldırgan kim olursa olsun derhal ve otomatik şekilde harekete geçecek bir milletlerarası mekanizma olmalıdır" (Akşam, 23 Nisan 1945, s. 1, 2).

Anlaşılacağı üzere Sadak, beş daimi üyenin tamamının hemfikir olmadıkça Güvenlik Konseyi’nin karar alıp uygulayamayacağını diğer taraftan ise Konseyin, veto yetkileri nedeniyle beş daimi üyenin aleyhine karar alamayacağını veya onların korumak istediği herhangi bir devleti cezalandıramayacağını öne çıkarmışıtır.

Şöyle ki kolektif emniyeti sağlamak beş büyük devletin katılım şartına bağlı kaldığına göre bir tek büyük devletin herhangi bir politika sebebi ile veto hakkını kullanması ihtimali bütün insanlığın hizmetini daima bozacak ve özellikle küçük devletleri daima bir korunma kaygisı içinde yaşatacaktır. $O$ halde bütün devletlerin dayanışmasına bağlı ve emin bir güvenlik için kesin bir pratik unsuru ortada yoktur ve durum da kolektif emniyete büyük yara açmaktadır (TBMM Zabıt Ceridesi, s. 172).

Fark edileceği üzere San Francisco Konferansı sürecinin Türk basını tarafından yakından takip edildiği ve özel bir yere sahip olan BM konusunun, gazete köşe yazılarınca ele alındığ görülmektedir. Gazetelerdeki yazarların ortak noktası ise büyük beklentilere gebe olan örgütün birçok zayıf noktaya sahip olacağını da öngörmeleridir. Özellikle barışı korumak adına hareket edecek Güvenlik Konseyi'nin daimi üyelerine verilen veto hakkını değerlendiren Türk basını böylece beş büyük devletin saldırı ve haksızlık suçunda bulunmayacağına inanılması üzerinden sulh ve emniyetin eskisinden dahi daha çürük bir pamuk ipliğine bağlı olduğuna dikkat çekmiştir.

\section{San-Fransisko'da Oy Usulü ve Veto (Nisan-Haziran 1945)}

\subsection{Türkiye'nin San Francisco Konferansı'na Davet Edilmesi}

Yalta Konferansı'nda veto ve üyelik meselesi ele alınırken, üyelik meselesinde Ruslar, Rusya ile diplomatik münasebetler kurmamış olan Güney Amerika devletlerinin ve Türkiye'nin Birleşmiş Millet Teşkilatına üye olarak alınmamalarını istemiştir. Tartışmalardan sonra, 1 Mart 1945'e kadar ortak düşmana savaş ilan etmiş olanların üyeliğe alınması kabul edilmiştir. Bunun üzerine 23 Şubat 1945'te Almanya ve Japonya'ya savaş ilan eden Türkiye, 5 Mart 1945’te Birleşmiş Milletlerin kurucu üyeleri arasında yer almak üzere San Francisco Konferansı'na davet edilmiștir (Armaoğlu, 2016, s. 361). Söz konusu davet, Amerika Büyükelçisi Steinhardt’in Türkiye Dışişleri Bakanını ziyaret ederek, Türkiye'nin San Francisco Konferansı'na, Amerika dâhil dört devlet adına, Amerika Hükümeti tarafından davet edildiğini bildirmesiyle gerçekleşmiştir (Akşam, 7 Mart 1945, s. 1). ${ }^{3}$

Harpten sonra devamlı ve istikrarlı bir sulh kurmak için milletlerarası bir teşkilat kurmayı hedef tutan bu konferansa davet edilen Türkiye’nin, büyük devletlerin birinin arkasına takılmayıp küçük devletler grubunda rol oynamaya çalışmasını öne çıkaran Sertel, durumu şöyle özetlemiştir:

\footnotetext{
3 Ayrıca Stettinius, San Francisco Konferansı'na katılacak bütün delegelere tebligat yaparak her delege heyetinin tadil tekliflerini sebepleriyle birlikte 7 Nisan'a kadar merkez kongre bürosuna gönderebileceklerini belirtmiştir. Ancak Türk murahhas heyeti tadil tekliflerini makul gerekçeleriyle büroya sunmamıştır; (TBMM Zabıt Ceridesi, s. 173).
} 
"Bu teşkilatta şimdiden beliren ve küçük milletleri kısmen endişeye düşüren nokta; tasarıda büyük ve küçük devletler arasında bazı farklar gözetilmesidir. Daha adil, daha devamlı ve daha istikrarlı bir barış sağlamak için büyük devletler Güvenlik Konseyinde beş büyük devletin ittifakı olmadıkça karar verilmemesini uygun görmüşlerdir. Küçük devletler, kendilerinin de eşit haklara sahip olmaları gereği üzerinde durabilirler. Yalnız seslerini duyurabilmek için önceden kendi aralarında anlaşmaları büyük devletlerin ihtiraslarına set çekecek bir cephe kurmaları gerekir. Fakat küçük devletlerin her biri, kendi menfaatlerinin birleştiğini zannettiği büyük devletlerin tarafinı tutarsa o vakit büyük devletlerin nüfuz bölgeleri zihniyetine yardım etmiş olur ki konferansın maksadını yok etmiș olurlar. Amerika'nın konferansta maksadı bütün dünya milletleri arasında yarınki dünya teşkilatı etrafında bir işbirliği kurmaktır. Fakat daha şimdiden bazı büyük devletlerin konferansta fazla oy sahibi olmak hevesine kapıldıkları ve küçük milletleri de kendilerine oy kazanmak için davet ettikleri görülmektedir. Küçük milletler bu tuzağa düşerlerse hem kendi istiklallerini kaybetmiş olurlar hem de harp sonrası dünya teşkilatının akamete uğramasina sebep olabilirler" (Tan, 7 Nisan 1945, s. 1, 2).

Diğger taraftan Türkiye'nin, San Francisco Konferansı'na katılmakla BM’nin harp sonrasına ait vereceği bütün tedbirleri kabule mecbur olacağını belirten Sertel'e göre, böylece Türkiye hem BM camiasına girecek hem de onlarla siyasi, iktisadi, askeri ve içtimai sahalarda işbirliği yapmak mevkiinde bulunacaktır. Bu nedenle Sertel'in yorumuyla, yarınki dünya düzeninin temellerini atacak San Francisco Konferansi'na katılacak olan Türkiye açısından bu konferans önem arz etmektedir (Tan, 7 Nisan 1945, s. 1,2). Davet gereği harekete geçen Türk murahhas heyeti Dumbarton Oaks projesi adıyla anılan metni incelemiş, hem nazari ve hukuki hem de siyasi bakımdan Türk hükümetinin görüşlerini alarak yola çıkmıştır (TBMM Zabıt Ceridesi, s. 156).

San Francisco Konferansı'nın 30 Nisan oturumunda Türk temsilcileri adına Hasan Saka söz almıştır. Dumbarton Oaks projesi hakkındaki düşüncelerini genel sekreterliğe bildiren Saka yeni yasanın; bütün anlaşmazlıklarda adalete ve hakka uygun olarak çalışması noktasında kanaatini ortaya koymuştur (Tan, 3 Mayıs 1945, s. 1). Türk heyeti, Dumbarton Oaks planında istediği tadilleri iki maddede toplamıstır. i. Büyük milletlere diğer devletlerden daha geniş yetkiler tanınmakla beraber Güvenlik Konseyi'ndeki geçici azalıklar sayısının arttırılması ve buna koşut olarak herhangi bir karar alınabilmesi için gerekli olan en az oy miktarının çoğaltılması. ii. Genel Kurul'un yetkilerinin genişletilmesi. Sertel'e göre, bu iki önemli nokta ile Türk heyeti Genel Kurulun Güvenlik Konseyi'ne karşı yetkilerinin arttırlmasını istemektedir. Bu suretle varılmak istenen hedef Genel Kurulu hakikaten bir milletlerarası parlamento haline getirmek, küçük milletleri büyük devletlerin tahakkümü altına düşürüyor göstermekten kurtarmaktır. Bu tezin diğer küçük milletlerden bazıları tarafindan da ileri sürüldügünü belirten Sertel'e göre, Türk tezi öteki küçük milletlerden de taraftar bulmakta güçlük çekmeyecektir (Tan, 5 Mayıs 1945, s. 1, 2). Fark edileceği üzere Türk tezi, sorumluluğu geniş olan büyük devletlere diğerlerinden fazla yetki verilmesi esasına itiraz etmemektedir. Ancak milletlerin temsilcilerini bir araya topladığ için her türlü yetkinin kaynağı sayılması gereken Genel Kurul'un hem yetki hem de denetleme hakkının genişletilmesini, Güvenlik Konseyi'nin bünyesinde beşlerin dışındaki devletler lehine bir değişiklik olmak üzere geçici üye sayısının biraz çoğalılımasını ve karar alabilmek için bir araya gelmesi gerekli bulunan oylar sayısının da artırılmasını istemektedir. Türk Heyetinin ileri sürdüğü önemli bir nokta; anlaşmazlığın yargllama suretiyle çözülmesi yoluna girildikten sonra bu yolda devam edilmesinin ve yargilama sonunda verilen karara uyan tarafin, BM kurulunca himaye olunmasının, hukuk esaslarına daha uygun olacağına yöneliktir (Tekeli, Ulus, 6 Mayıs 1945, s. 1, 2). Bu yönüyle Türk tezi, ihtilâfların hak ve adalet prensibine uygun bir surette çözümünü talep etmiştir. Dumbarton Oaks projesine göre, Güvenlik Konseyi, bir ihtilâfa el koyunca artık Genel Kurul, o işten elini çekecek, anlaşmazlığın barış veya cebir yoluyla çözümü sadece Güvenlik Konseyi'nin hakk1 olacaktır. Türk tezi, bu durum karşısında, Genel Kurul'a bir derece yetki verilmesini ve Güvenlik Konseyi'nin, anlaşmazlıkların çözüm yolunda alacağı ve uygulanmasını gerekli göreceği tedbirlerden Genel Kurul'a haberdar etmesini gerekli görmüştür. Saka demecinde ihtilâfların herhangi bir safhasında anlaşmazlığın çözümü için barış, adalet ve yargılama yollarına girildiği takdirde Güvenlik Konseyi’nin neticeye kadar beklemesini ve işi adaletin karanna bırakan tarafin himaye edilmesi için BM projesine hüküm konmasını dile getirmiştir (Tekeli, Ulus, 15 Mayıs 1945, s. 1, 2). 
Türkiye Dışişleri Bakanı Saka, Reuters Ajansının özel muhabirine verdiği beyanatta ${ }^{4}$ savaşın önlenmesi için çalışacak bulunan bütün ülkelerin aşağıdaki ülkü etrafında birleşeceklerine şöyle açıklık getirmiştir:

"Türk heyeti buraya, konferansın muvaffakıyetine yardım etmek gayesiyle gelmiştir. Bu muvaffakıyet, velev ki daha uzak bir tarihte gerçekleşecek olsun, bundan şüphe etmiyorum. Bu konferansa davet eden veya edilen, büyük ve küçük bütün memleketlerin ortak gayesi, yeni ve devamlı bir emniyet nizamı kurmak ve istikbalde harpler önlemektir. Bu hedef birliğine binaen San Francisco Konferansı'nın, herkesi memnun edecek bir müessesenin temellerini atacağından ve çok olumlu neticeler tahakkuk ettireceğinden şüphe etmiyorum. Temelleri şimdi atılacak olan bina harp sonrası dünyasında milletlerarası güvenlik duygusu ve işbirliği ile birlikte gelişecektir”" (Ulus, 16 Mayıs 1945, s. 1).

Saka, Türkiye'nin de dünya barış ve güvenliğini sağlamak yolunda büyük küçük bütün ülkelerle işbirliği içerisinde çalışacağına dair iyi niyetlerini belirtse de Recep Peker TBMM'de yaptığı konuşmasında Saka'nın konferansta özellikle veto meselesinin açtığı büyük yara konusunda yeterince çalışmadığını öne sürerek bu durumu şöyle eleştirmektedir:

"Nüfusumuz ve teknik kabiliyetimiz itibariyle biz büyük devletler arasında değiliz. Bundan dolayı kendi üzerimize herhangi bir ihtirasla silahlı bir saldırganlık yöneltecek devlete karşı, Güvenlik Konseyi mekanizmasının pürüzsüz işlemesini istemek hususunda hak sahibiydik. Konferansta bunu istemek bizim vazifemizdi. Dışişleri Bakanımızın söylediğine göre delege heyetimiz bazı teklifler yapmışlar, bence yapılacak ve kuvvetle müdafaa edilecek en lüzumlu ve esaslı teklif buydu. Bize verilen açıklamaya göre bazı küçük devletler ve İngiliz Dominyonları buna itiraz etmişler. Şimdi büyük devletlerin veto hakkı ile beraber bu anlaşmayı kabul eden küçük bir devlet, bir gün kendine ya büyük bir devletin yapacağ1 ya da kendisinden daha kuvvetli diğer bir küçük devletin büyük devletlerden birinin veto hakkını temin ederek uygulayacağı istilayı Birleşmiş Milletler Antlaşması'nın teminatından mahrum olarak ve peşinen kabul ediyor demektir. Bundan dolayı büyük bir dünya eserini vücuda getirmek faaliyetine iştirak ederken bu sakıncaya karşı durarak heyetimizin çalışması lazımdı. Bunun dışında hiç olmazsa büyük devletlerin veto aleyhine itiraz yapan küçük devletlerle birlikte çalışabilir, bu noktada çoğunluk elde edemesek bile bariz bir hakkı koruyarak hem memleketimizin bekası için esaslı noktada uyanık bulunduğumuzu gösterir hem de milletlerarası bir teşkilatın mükemmeliyetine çalışarak Türkiye'nin şeref ve itibarını yükseltmiş olurduk" (TBMM Zabit Ceridesi, s. 172, 173).

Türk heyeti konferansta, BM Genel Kurulu'nun yetkilerinin genişletilerek uluslararas1 sistemin demokratik olması gerekliliği üzerinde durmuş ancak Recep Peker'in de ifade ettiği gibi dünyadaki güç dengesini yansitan BM Güvenlik Konseyi'nin eksik ve kusurlu yönleri üzerinde yeterince kendini ifade edememiştir.

\subsection{San Francisco Konferansı'nın Açılması ve BM'nin İmzalanması (Nisan-Haziran 1945)}

San Francisco Konferans1, Truman'ın radyo vasıtasıyla yaptı̆̆1 açılış konuşmasıyla çalışmalarına başlamıştır. Truman'ın açılış nutku şöyledir (Cumhuriyet, 26 Nisan 1945, s. 1):

"Hedefimiz adalete dayanan bir barış dünyası kurmaktır. Bu işi başarmakla, dünya barışının mimarı olacaksınız. İnsanlık bu sayede sürekli barışa kavuşacak ve buhranlar içinde yüzmekten kurtulacaktır. Hepiniz bu işi başarmak için milletlerimiz namına tam yetkiye sahip bulunuyorsunuz. En büyük hedefimiz adalete dayanan bir dünya barışıdır. Bu barışı kurmak için bütün dünya milletlerinin elbirliğine güveniyoruz. Bunun için barışı kundaklayacak bütün gizli kuvvetleri, dünyaya hâkim olmak isteyen bütün tecavüz kuvvetlerini ortadan kaldıracağız. Büyük, küçük bütün dünya milletleri barış içinde yaşayacak ve büyükler dünyaya hâkim olmak değil fakat dünyaya hizmet için çalışacaklardır. Biz, harpte elbirliği yaparak bütün güçlüklere karşı gelmiş olduğumuz için barsşa hizmet yolunda da bütün güçlüklere galip geleceğimize inanıyoruz. Savaş esnasında infirat siyasetine güvenmememize imkân bulunmadığına göre barış içinde de infirat siyasetine sapmamıza imkân yoktur. Biz milletler arasındaki bütün ihtilafların ortadan kaldırılacağına ve hepsi arasında dostluğun hüküm süreceğine inanıyoruz. Esas hedefimiz, bundan sonra

\footnotetext{
${ }^{4}$ Saka Reuters muhabirine yaptı̆̆ açıklamada ayrıca Türkiye'de savaştan sonra her türlü demokratik oluşumun gelişeceğini söylemiştir. Saka'nın açıklamasını Türk demokrasinin daha ileri bir aşamaya geçişinin ilk emaresi biçiminde yorumlayan Tan yazarı Sabiha Sertel, olağanüstü savaş şartlarının sona ermesiyle ülkede demokrasinin geliştirilmesinin ve vatandaşlara geniş demokratik haklar verilmesinin zamanı geldiğine açılık getirmiştir (Öztekin, 2016, s. 265).
} 
herhangi milletin silaha başvurarak tecavüz siyasetini yürütmesine imkân vermemektir" (Cumhuriyet, 26 Nisan 1945, s. 1).

Anlaşılacağı üzere, bütün milletleri tatmin ve hoşnut edecek adaletli, haklı barışın yapılması ilk şart olarak belirmektedir. Bunun ardından dünya barışını güven altında tutabilmek için her türlü saldırı ve harp ruhunu imha edebilmek başlıca şarttır (Benice, Son Telgraf, 27 Nisan 1945, s. 1, 3). Her iki meselede de Amerika'nın tavıı açıktır. Truman'ın, dünyayı genel ve devamlı bir barışa götürmek ve her millet için güvenli bir dünya yaratmak üzere belirlediği ana prensipler de bütün milletlerce benimsenecek niteliktedir. Truman bu konuda șöyle demektedir: "Büyük küçük bütün dünya milletleri sulh içinde yaşayacak ve büyükler dünyaya hâkim olmak değil fakat dünyaya hizmet için çalışacaklardır” (Benice, Son Telgraf, 26 Nisan 1945, s. 1, 3; İkdam, 26 Nisan 1945, s. 1)

Truman'ın, dünyayı genel ve devamlı bir barışa götürmek ve her millet için güvenli bir dünya yaratmak üzere belirlediği ana prensiplerin bütün milletlerce benimsendiğini belirten Sadak Truman'nn söylediği nutuktan hareket ederek Amerika'nın infirat politikası gütmeyeceği fikrine şöyle ulaşmışıı: "Herhangi bir milletin silaha başvurarak saldırgan siyaseti yürütmesine imkân verilmeyeceğini ilave eden Truman, böylece savaşta olduğu gibi barış terazisine de Amerika'nın ağırlığını koyarak, infirat politikasına ihtiyaç kalmadığını açıkça ilan etmiştir." Sadak’a göre, hiçbir menfaat gözetmeden sadece milletlerin hürriyeti kaygisiyla Avrupa savaşına atılan Amerika gibi idealist bir milletin tam bu sırada göreve gelen Başkanı tarafindan söylenen bu sözler ümit vericidir (Akşam, 27 Nisan 1945, s. 1, 2). Böylece Truman, Amerika'nın artık infirat siyaseti gütmeyeceğini kendi ağzından teyit etmiştir.

Genel olarak San Francisco Konferansı'nda, dünyayı genel ve devamlı bir barışa götürmek üzere her millet için güvenli bir dünya yaratmak fikrini öne süren Amerika'nın bu yolda sona ulaşana dek gayret etmesi gerekliliği Türk basını tarafından dile getirilmiştir. Ancak böyle cihanşümul bir netice almak adına sadece Amerika'nın bu yolda çaba göstermesini tek başına yeterli bulmayan Yeni Sabah gazetesine göre, irili ufaklı bütün milletlerin aynı amaç doğrultusunda birlik ve gayreti de şüphesiz böyle bir birliğe güç katacaktır (Yeni Sabah, 27 Nisan 1945, s. 1). Bir bakıma basitçe kendi sınırları içerisine çekilemeyecek Amerika’nın en önemli hedefi; liberal demokratik düzeni dünya çapında ulusal zemine oturtmak ve kolektif güvenliği ön plana taşıyan uluslararası bir teşkilat inşa edilmesinde rol üstlenmektir.

Türk basını özellikle Amerika’nın milletlerin hürriyetlerinin koruyuculuğunu üslenmesine yönelik memnuniyetini ortaya sermiştir. Zira en büyük çekincesi kuzey komşusu Sovyet Rusya'nın Mart-Haziran 1945 Notası kapsamında milli bütünlüğune aykırı biçimde hem toprak hem de Boğazlarda üs talebiyle karşı karşıya kalan Türkiye için (Başarır, 2019, s. 1444, 1445) infirat politikasından uzak duracağını beyan eden Amerika'nın barıştan ve istikrardan yana tavır ve duruşu biraz olsun rahatlatıcı gelmiştir. Kendi bütünlüğüne karşı ileri sürülen Sovyet taleplerinin savaş sonrası dönemde uluslararası ilişkilerin tanzimi ilkelerine aykırı olduğuna dikkat çekerek, Amerika'nın bu konuyla yakından ilgilenmesini arzulayan Türkiye; bilinmezlik içerisinde kalmak yerine demokrasinin bekçiliğini yapacağını vurgulayan Amerika'nın da dâhil olduğu BM Teşkilatı içerisinde aynı yolda gayret sarf edeceğini ortaya koymaktadır.

Konferansta, BM'nin asıl davası ise Dumbarton Oaks tasarısını müzakere ve gerektiğinde tadil ederek bir milletlerarası barış ve işbirliği teşkilatı meydana getirmektir. Bir nevi "dünya hükümetinin" anayasasını kaleme almaktır (Belge, Tanin, 28 Nisan 1945, s. 1). Konferansta tüm dünya milletlerini kapsayan bir anayasa hazırlanırken, Dumbarton Oaks'ta belirlenen oy meselesi de gözden geçirilecektir. Sadak, oy meselesi üzerinden, savaşın bütün fedakârllğını omuzlarına alan büyüklerin birleşmedikçe savaş veya savaşa varacak kararların verilemeyeceğine yönelik fikirleri eleştirmektedir. Çünkü yazara göre, barışı ve güvenliği korumak yükü sadece üç devlete birakılmak yerine, yeni kurulda hak ve vazife isteyen bütün devletlere dağıtılmalıdır. Bu devletlere "ortanca" adını veren Sadak, büyük devletlerden başka diğer devletlerin de güvenliği korumak ve işgale karşı koymak için harekete geçmeyi kabul etmeleri durumunda, büyük- küçük farkının azalacağını aktarmaktadır. Buradan hareketle Sadak, büyüklerin fedakârllğına karşllı; küçüklerin hükümranlık haklarından bir derece vazgeçmelerinin istenemeyeceğini ve bulunacak şekil ne olursa olsun saldırgana karşı (bu saldırı kimden gelirse gelsin) hemen ve otomatik şekilde harekete geçecek biçimde bir mekanizmanın kurulması gerektiğini öne çıkarmaktadır. Neticede Sadak, altı yıllık görülmemiş savaştan sonra, insanlık ve hürriyet prensipleri uğruna bu kadar can veren düssman karşısında zafere kadar 
birleşmeyi bilen milletlerin, karşlıklı iyi niyetlerinin ilk denemesi olan San Francisco Konferansı'nın uzun tarihi sürecindeki sayısız eşleri gibi talihsiz çıkmamasını dilemektedir (Akşam, 25 Nisan 1945, s. 1, 2).

San Francisco Konferansını yorumlayan Nadir Nadi de Sadak gibi büyük güçlerin oy meselesinde üstünlük elde etmesini eleştirel bakış açısıyla değerlendirmektedir. Nadi, aşağıda saydığı sebeplerden ötürü San Francisco Konferansında tartışması yapılarak yasa haline getirilecek konuların hiç de kolay çözülemeyeceğini ve dünya teşkilatı inşa edilirken karşılaşılan en önemli güçlügün oy meselesi anlaşmazlığına dair olacağını şöyle dile getirmektedir:

"Hukuk kuramcılarına bakılırsa, Dumbarton Oaks’ta verilen karar, barıș teșkilatının sağlamlığını korumaktan uzaktır. Saldırgan bir devlete karşı harekete geçmek için beş büyük devletin oybirliği şart koşulursa, büyük devletler, hatta büyük devlete güvenen küçük devletler, cezadan kurtuluyor demektir. Bu ise, dünya güvenliğini pamuk ipliğine bile bağlayamayacak bir tedbir daha doğrusu tedbirsizliktir. Büyük devletlere sorarsanız, onlar da, harplerde en büyük fedakârlığa kendilerinin katlandığını, o halde aralarında oybirliği bulunmadıkça verilecek kararların dünya barışı adına zararlı olacağını söylüyorlar. Mesele objektif bir görüşle ele alındığı zaman başka bir nokta üzerinde de durmak mümkündür: Farz edelim ki, oybirliği esası bırakıldı da çoğunluk esasında karar kılındı. Herhangi bir anlaşmazlık çok şiddetli bir şekil alırsa ne olacak? Harp ihtimalleri ufku baştan başa kararttığı zaman, herhangi bir hukuk mekanizmasıyla barış güneşini parlatmaya imkân var mıdır?” (Nadi, Cumhuriyet, 26 Nisan 1945, s. 1, 3).

Nadir Nadi'nin başmakalesinden sonra Sertel "Türk Gazeteleri Neden Bu Kadar Kötümserdir?" başlıklı bir makale yazmışır. Yazar makalesinin girişinde "Hemen umumi denilecek derecede hâkim bir kanaat halinde ileri sürülen bu kötümserlik neden? Niçin Türk okuyucusu hem San Francisco Konferansına, hem de Müttefikler arasındaki her türlü anlaşmalara şüphe ile bakıyor?” sorularını yönelterek, bu hususları açıklamaya çalışıı̧tır. Bu sorulara cevap olarak Sertel, Türk gazetelerinin çoğunun Müttefiklerin zaferine inanmayarak, memlekete kötümser hava yaydıklarını, ancak hadiseler bu düşüncelerinde hataya düştüklerini kanıtlayınca da bu kez Müttefikler arasında er geç bir geçimsizlik başlayacağını umduklarını öne çıarmaktadır. Bu beklentileri etrafında San Francisco Konferansı'nda şimdiden oy verme meselesinde (büyük devletlerin fazla oy sahibi olmaları, küçük devletleri esir vaziyetine düşürecek ve onların işbirliği yapmasına mani olacaktır) anlaşmazlıklar olduğunu dile getirerek bu konferanstan insanlık, sulh, hürriyet ve istiklal adına bir şey beklenemeyeceğini vurguladıklarını söylemektedir. Sertel, böyle düşünen Türk gazetelerinin şimdiye kadar hep Almanya'nın muzaffer olacağını beklemelerinden, onların kafalarının ve gönüllerinin Alman zaferine göre ayarlanmasından dolayı, Müttefiklerin zaferi kesinleştikten sonra bile içlerinden bazılarının hala doğruyu göremediklerini iddia etmektedir. Böyle düşünen basın yazarlarının aksine, Müttefiklerin San Francisco'da devamlı barış temin edecek bir teşkilatın vücuda getirilmesinde başarılı olacağına inanan Sertel, hatta bu teşkilatın hâlihazırda halledilmez denilen birçok ihtilafı kökünden söküp atacağını belirterek makalesini "Onun için San Francisco Konferansı, bizim sakat görüşlü gazeteci arkadaşların dileklerine ve tahminlerine rağmen başarılı olacaktır" (Tan, 27 Nisan 1945, s. 1, 2) diyerek bitirmektedir.

Güvenlik Konseyi'ndeki oy usulü San Francisco'da en fazla tartşsılan meselelerin başında gelmiştir. Ulus gazetesinde yazan Esat Tekeli'ye göre, harbi önlemek sorumluluğu geniş ölçüde büyük güçlere bırakılmalı fakat kendilerine bu sorumluluk derecesinde yetki verilmelidir. Tekeli, Dumbarton Oaks projesinde beş büyük devletin daimi üye bulunduracağı Güvenlik Konseyi'ne milletlerin temsilcilerini bir araya toplayan Genel Kuruldan daha fazla yetki verilmesi ve kendilerinin ilgili bulundukları anlaşmazlıklarda bile bu beș devlete veto hakkı tanınmasının da hep bu sorumluluk derecesinde yetki verme formülüyle izah edildiğine açıklık getirmektedir. Ancak Tekeli’ye göre veto hakkı yukarıdaki gibi değerlendirilse de, milletlerarası demokrasi kurmak isteyen büyük güçlere üstlendikleri sorumluluklarla ve ehemmiyetlerle orantılı bir pozisyon sağlanmalıdır. Bu açıdan konferansta veto meselesi üzerine eleştirilerini ortaya koyan ülkeler büyük küçük farkı olmaksızın her millete eşit hak verilmesini dilemekte ve projede veya Yalta Konferansı kararlarında buna uymayan noktaların kaldırlmasını istemektedirler (Ulus, 6 Mayıs 1945, s. 1, 2).

Güvenlik Konseyi'nin daimi üyelerine verilen veto hakk1 Avam Kamarası'nda söz alan Mr. Durbin'e göre de önemli bir kusurdur. Zira tüzügün şartları altında herhangi bir büyük gücün kendisine karşı güç kullanımını veto etmesi mümkündür. Yani büyük savaşlar büyük güçler tarafından yapılmıştır (Avrupa 
tarihi her zaman bir saldırgana sahip olmuştur.) Saldırganın her zaman Avrupa ülkelerinden çıkmasını Avrupa tarihinin üzücü dersi biçiminde niteleyen Durbin can alıcı soruyu yöneltmiştir: "O halde Güvenlik Konseyi'ndeki büyük güçlerden biri dünya barışını tehdit ederse vaziyet ne olacaktır?" Böyle bir durumun ortaya çıkmaması Durbin'e göre sadece büyük güçlerin savaş içerisindeki işbirliklerini, dostluklarını ve iyi niyetlerini korumalarına bağlıdır (HC Deb 22 August 1945 vol 413 c707). Durbin’in sorusuna yönelik Mr. Lipson, Güvenlik Konseyi içerisinde yer alan büyük güçlerden birinin dünya barışını tehdit etmesi durumunda Tanrı'nın insanlığa yardım etmesini temenni etmektedir. Lipson da tıpkı Durbin gibi büyük güçlerin dünya barışını güvence altına almalarını ve sürdürmelerini kendi aralarındaki ahenkli işbirliğini devam ettirmeleriyle mümkün görmektedir (HC Deb 22 August 1945 vol 413 c727).

Anlaşılacağ1 üzere, konferansta, büyük devletlerin veto hakkının kaldırılmasından ziyade değiştirilmesine yönelik tartışmalar yaşanmıştır. Avusturalya oy formülünde vetoyu bertaraf edecek bir tadilât teklif etmiş ve büyük devletlerin muhalefetine rağmen Avusturalya teklifi; Brezilya, Şili, Kolombiya, Küba, İan, Meksika, Hollanda, Yeni Zelanda ve Panama'dan 10 olumlu oy almıştır (Çubukgil, 1950, s. 180). Bu devletlerden Hollanda ve Meksika temsilcileri Durbarton Oaks tekliflerini tadil ve sslahına dair niyetlerini açıklamışlardır. Küçük devletlerin sözcüsü konumundaki bu iki ülke, üç büyük devletin Dumbarton Oaks ve Yalta'da üzerlerine almak istedikleri yetkileri, tesirsiz birakacak kadar azaltmak istememekle birlikte hakkaniyet ve adalet lehine daha kuvvetli tedbirlerle bu otoriteler ve yetkilere karşı küçük devletleri korumak noktasında 1srar etmişlerdir. Bir bakıma bu ülkeler realitenin mecburiyetine bağlı kalmakta ancak idealleri gerçekleştirmek ve adaleti hâkim kılmak suretiyle başarılı olmak arzusundadırlar (Ulus, 27 Nisan 1945, s. 3). Bundan dolayı yukarıdaki ülkeler, anlaşmazlıkların barışçl çözümüne yönelik tüm tavsiyelere oy vermelerinin basit, nitelikli olmayan bir çoğunluk tarafindan yapılması gerektiğini öne sürmüşlerdir (The Times, 23 Mayıs 1945, s. 3).

Büyük güçlerin veto hakkının niteliğine yönelik teklifler devam ederken, büyük bir gücün vetosunu bir anlaşmazlığın tartışılmasını veya soruşturulmasını önlemek için kullanabileceğini de belirtmişlerdir. Hâlihazırda, "Büyük Beş" arasında bile bu konuda bazı şüphelerin bulunduğunu öne çıkaran Sir Alexander Cadogan, vetonun ön soruşturmayı önlemek veya konseyin tarafları müzakere, tahkim veya adli çözüm yoluyla anlaşmazlıkları çözmeye çağırmasını engellemek için çalışamayacağı görüşünü ifade etmiştir. Böylece Cadogan "Büyük Beş”in etken olduğu Güvenlik Konseyi'nin birçok meseleyi açıklı̆̆a kavuşturmak için yararlı işler yapabileceğini ifade etmiştir (The Times, 23 Mayıs 1945, s. 3).

Büyük güçler, beş süresiz üyenin grup halinde vetolarını kullanmalarını mümkün değerlendirmektedir. Ancak diğer taraftan büyük güçler, Güvenlik Konseyi’nin faaliyetini sekteye uğratmak maksadıyla süresiz üyelerden daha ziyade vetolarını kullanacaklarının iddia edilemeyeceğini de aktarmaktadırlar. Böylece vetonun seyrek ve neticeleri çok mühim olan meselelerde kullanılacağı zannedilmişti. Ne var ki bu ümit doğru çıkmadı. Zorlayıcı tedbirler hakkında süreli üyelerin ittifakı şart olunca beş büyüklerden hiçbirinin kendisine konacak zorlayıcı tedbirlere razı olmayacağı tabiî idi. Birçok küçük devletler ve eleştirmenler bu hususun çok önemli ve büyük devletlerin "kanun üstünde" olduğu manasının çıkarıldığını iddia etmişlerdir (Çubukgil, 1950, s.180, 181). Fenik bu durumu "küçüğü küçük, büyüğü büyük bırakmak" biçiminde özetlemiş̧tir (Ulus, 8 Nisan 1945, s. 1).

Tartışmalar neticesinde Avusturalya teklifi ret edilince Yalta formülü oya konmuş ve oylamada 15 ülke çekimser kalırken, 2 ülke olumsuz, 30 ülke olumlu oy kullanmış ve böylece Yalta formülü kabul edilmiştir. Kolombiya ve Küba olumsuz oy verirken; Türkiye lehte oy vermiştir. Bu suretle Yalta formülü Birleşmiş Milletler Anlaşmasına aynen girmiştir. Bundan sonra veto meselesi ve Güvenlik Konseyi’ndeki oy işi Birleşmiş Milletler Teşkilatı'nda sık sık bahis konusu olmaya başlamıştır (Çubukgil, 1950, s. 181).

İngiliz Başbakanı Attlee'ye göre konferansta, büyük güçlere, üstlendikleri sorumluklarla ve ehemmiyetlerle orantılı bir pozisyon sağlanırken, kuşkusuz en kritik tartışmalar ve müzakereler, büyük güçlerin küçük ulusların haklarını koruyup korumaması meselesinde yaşanmıştır. Özellikle veto konusunda; büyük güçlere kendi davalarında yargıç olma hakkı verildiği ileri sürülürken; Attlee büyük güçlere verilen istisnai durumun, üstlendikleri özel yükümlülüklerden kaynaklandığını ileri sürmüştür. $\mathrm{Bu}$ özel konuda Attlee, tüm devletleri tamamen nüfuslarından, genişlik ve güçlerinden habersiz aynı seviyeye getirmenin basit bir yöntemle çözülemeyeceğine dair önemli bir mutabakat bulunduğunu sözlerine ilave etmiştir. San Francisco'da etraflica ele alınan veto meselesinin gerçekten de hararetli bir şekilde 
tartışıldığını, ancak sonunda, küçük devletlerin büyük güçlerin önerilerinin genel hatlarını kabul ettiğini belirtmiştir. Attlee’ye göre bu netice, tüzüğ̈̈n temelinin, dünyada var olan durumun gerçeklerine karşllk geldiğini takdir etmelerinden kaynaklanmışır. Nitekim büyük güçlerin birlikte anlaşmaması ve harekete geçmemesi kaçınılmaz biçimde örgütün yıkılması anlamına gelmektedir (HC Deb 22 August 1945 vol 413 c661).

Birleşmiş Milletler Anayasası 26 Haziran 1945 günü imzalanmıştır. İlk imzayı Çin temsilcisi, ondan sonra da Sovyetler Birliği, İngiltere ve Fransa imzalamıştır. Konferansın toplandığı memleket olmak itibariyle Birleşik Amerika, vesikayı en son imzalamıştır. Diğer 45 Birleşmiş Milletler temsilcileri de devletlerinin isimlerinin İngilizce alfabetik sırasına göre imzalarını atmışlardır. Birleşmiş Milletler delegeleri beyannameyi ittifakla kabul ettikten sonra, Başkan Truman şöyle konuşmuştur: "Şimdi imza etmiş olduğumuz beyanname sağlam bir vesikadır. İşte biz de bu vesika üzerine eskisine nazaran daha iyi bir dünya kurabileceğiz. Bundan dolayı, tarih sizi şerefle yâd edecektir. Avrupa'daki zaferle ve Japonya'ya karşı kazanılacak olan zafer arasında, bu bütün harplerin en tahripkârı harp arasında bizzat harbe karşı büyük bir zafer kazanmış oldunuz" (Tan, 27 Haziran 1945, s. 1).

Dünyaya hâkim olmak için kimseye bir hak verilmediğini de ifade eden Truman sözlerine şöyle devam etmiştir: "Bütün faşizm ölmemiştir. Hitler bitmiştir. Fakat onun muvazenesiz kafasının ekmiş olduğu tohumlar ve fenalık zihinlerde derin kökler salmıştır. Fakat Birleşmiş Milletler yine birleşmiş kalacaklardır" (Tan, 27 Haziran 1945, s. 1).

Türk milleti de yeni dünyadan gelen bu en yetkili, en gür hürriyet ve adalet sesini, yüreğinde hiç eksiltmeyen ümit, cesaret ve kahramanlık duygularına kata kata derin sayg1 ve sevinçle dinlemiş (Sadak, Akşam, 28 Haziran 1945, s. 1) neticede de kusur ve eksikliklerine rağmen BM Antlaşması'nı imzalamıştır. Türk hükümeti, eksik ve kusurlu bir vesikayı teşkilatsız, anarşi içerisinde bocalayan bir dünyada yaşamaya tercih ettiği için BM teşkilatına katılmayı kabul etmiştir (TBMM Zabıt Ceridesi, s. 157).

Türkiye dâhil 51 devletin BM Antlaşmasını imzalaması ile neticelenen San Francisco Konferansı büyük güçlerin savaş sonrasında da dünya egemenliğini düzenleme ve sürdürme ve karşılaştıkları sorunlara en üst düzeyde müdahale edebilme sorumluluğunu üzerlerine aldığı bir teşkilat ortaya çıkarmıştır.

\section{Sonuç}

Milletlerarası ilişkiler açısından önemli bir evre de BM Teşkilatı inşa edilmeye çalışılırken İkinci Dünya Savaşı Avrupa bölgesinde Almanya'nın teslim olmasiyla sona ermiştir. Uzak Doğu bölgesinde de Müttefikler Japonya üzerine yoğunlaşmıştır. İkinci Dünya Savaşı'nın galipleri Müttefikler, ABD'nin öncülüğünde yeni bir savaşı önlemek ve milletlerarası işbirliğini bir düzen içerisinde devam ettirmek amaciyla Dumbarton Oaks tasarısı üzerinden San Francisco'da bir konferans düzenlemek üzere harekete geçtiler.

Tüm insanlığı bir biçimde etkileyen savaş felaketinin acıları hâlihazırda sıcaklığını korurken Müttefik cepheyi oluşturan büyük güçler barış ve güvenliğin muhafazasında kendilerini görevli adlettiler. Savaş sırasında kendilerine daha fazla yetki ve sorumluluk yüklenmesi üzerinden yola çıkan büyük güçler, yeni kurulacak BM Teşkilatı içerisinde bulunan Güvenlik Konseyi'nde veto adıyla bilinen önemli bir pozisyon sağlamaya çalşstılar. Beş büyükler veto hakkını savaş sırasında işbirliği yaparak Mihveri yenilgiye uğratmalarından dolayı istikbaldeki barış ve güvenliği koruma işinden de sorumlu kılındıklarını gözeterek üzerlerine almışlardır. Bir bakıma büyük devletlerin savaş sırasında sağladıkları işbirliğinin zaferi getirmesi; barışı koruma yükünün de büyük güçlere bırakılmasına sebebiyet vermiştir. İkinci Dünya Savaşı'nın gelişim seyri ve MC'nin barışı korumaktaki başarısızlığı bu durumu ortaya çıkarmıştır. Bu nedenle Birleşmiş Milletler Güvenlik Konseyi (BMGK), BM'nin, üye ülkeler arasında güvenlik ve barışı korumakla yükümlü, en güçlü organı olarak tasarlanmıştır. BM'nin diğer organları sadece tavsiye kararı alabilirken, BMGK'nın kararları, tüm üye ülkeler açısından bağlayıcılık taşımaktadır. İkinci Dünya Savaşı'nın beş büyükleri de bu teşkilatın en önemli organında daimi üye olarak veto yetkisine sahiptir. Büyük güçlerin veto hakları, BM'nin bu organını tam anlamıyla demokratik bir kurum olmaktan çıkarmaktadır. Tartışmalar tam da bu noktadan meydana gelmiştir.

Türk basınında da ifadesini bulduğu gibi büyük devletlere tanınan veto hakkı; aslında sorumluluk ve yükümlülüklerde olduğu gibi alınacak kararlara tesir bakımından eşitlik getirmemekte ve dolayısıyla bu 
demokrasi esaslarıyla çelişmektedir. Diğer taraftan basın tarafindan eleştirilen başka bir durum kolektif emniyetin beş büyük devletin beşinin katılım şartına bağlı kalması nedeniyle büyük devletlerden birinin herhangi bir politika sebebiyle veto hakkını kullanma ihtimalidir. Nitekim dönemin basınına göre böyle bir durum bütün insanlığın güvenliğini tehdit edebileceği gibi; özellikle küçük devletleri daima büyük bir devletin himayesi altında korunma kaygısı içinde yaşatabilecektir. Pürüzsüz bir kolektif emniyet Sadak'ın nazarında, kurulacak emniyet teşkilatıyla, büyük devletlerin işbirliğinden bağımsız olarak harekete geçebilmeli ve herhangi bir saldırı karşısında otomatik şekilde işlemelidir. Nitekim dönemin bazı gazetelerine göre siyasetleri, menfaatleri, insanların ve milletlerin hayatı hakkında görüş ve düşünüşleri, tarih ve coğrafyaları da farklı bulunan büyük güçlerin barışı korumak adına sürekli birlik içinde kalacaklarına güvenmek barışı pamuk ipliğine bağlamış vaziyettedir.

Basının bu bakış açısı aslında BM Teşkilatı'nın mükemmel bir eser olmadığını ortaya koymaktadır. Tan'da yazan Sertel ise San Francisco Konferansı hakkında olumsuz yorum yapan gazetecileri eleştirerek er geç dünyada demokrasinin inşa edileceğini belirtmektedir. Konferansta bir araya gelen büyük güçlerin tüm dünya ulusları için barış sağlayacak bir teşkilat kurarak demokrasi adına hareket edeceklerini öne çıkaran Sertel, değişimden yana milletlerarası teşkilatın kuvvetlenmesiyle hür insanların yaşadığ1 demokrat bir dünyanın ortaya çıkacağını ifade etmektedir. Böylece demokrasinin destekleyicisi Sertel, Türkiye'nin de yeni dünya şartlarına ayak uydurarak konferansta bir araya gelen büyük güçlerin oluşturmaya çalıştığı teşkilat çatısı altında yer almasını arzulamış ve bu durumu desteklemiştir. Türkiye gibi San Francisco Konferansı'na katılan diğer bütün büyük ve küçük güçler, tüm insanlığ1 derinden etkileyen harbin felaketinin hâlihazırda sıcaklı̆̆ını korumasından dolayı istikbalde barış ve güvenliği dünya ölçüsünde korumak ve kurtarmak amacıyla bu teşkilata imzalarını koymuşlardır. Türk hükümeti de diğer imzalayıcılar gibi kargaşa ortamına sahip bir dünyada yaşamaktansa eksik ve kusurlarına rağmen bir teşkilat içerisinde bulunmayı uygun nitelemiştir. Ne de olsa Türkiye kurulduğu andan itibaren kendi güvenliğini tüm dünya milletlerinin güvenliği içinde gerçekleştirmeye çalışmış ve bu uğurda her türlü fedakârlığ1 sergilemiştir. "Yurtta sulh, cihanda sulh" ilkesiyle hareket eden Türk hükümeti, dünyanın uzak bir köşesindeki savaşın hatta sadece bir anlaşmazlığın veya rahatsızlı̆̆ın neticeleri itibariyle bütün milletlerin hayatlarını etkilediğini çok iyi tecrübe etmiştir.

Türkiye'nin uluslararası bir teşkilat içerisinde yer almak istemesinin bir başka nedeni de savaş sonrasında değişen siyasi gelişmeler argümanıyla hareket eden Sovyet Rusya'nın Mart-Haziran 1945 notalarıyla Türkiye'nin doğu sınırında değişiklik ve Montreux Antlaşması'nın yeniden gözden geçirilmesi yönündeki talepleridir. İkinci Dünya Savaşı süresince kuzey komşusunu tedirginlikle takip eden Türkiye, harp ertesi devrede Sovyet talepleri ile karşı karşıya kalınca demokrasinin öncü devleti ABD'nin infirat siyaseti izlemeyeceğine dair açıklamalarını da basın kanalıyla memnuniyet verici bir hadise biçiminde değerlendirmiştir. Sovyet Rusya'nın Türkiye'ye yönelik isteklerinin yakın gelecekte nasıl şekilleneceğine yönelik çıkarım yapmakta zorlanan karar alıcılar, dünya dengeleri açısından da önem arz eden bu meselede Özellikle ABD’nin desteğine güvenerek yeni dünya düzenine ayak uydurmak üzere bir teşkilat içerisinde yer almak istemiş ve savaş sonrası bu devletle yakın ilişkiler kurmuştur.

Milletlerarası barış ve emniyetin hızlı bir şekilde sağlanması adına eksik ve kusurlu BM Teşkilatı'na imza koyan Türkiye, diğer katılımcılar gibi sosyal ve siyasi hayatı düzenlemek üzere kurulan teşkilatların ilk kuruluşlarında mükemmel olmayacağının ancak zaman içerisinde eksik yönlerinin giderilebileceğini de göz önünde tutmuştur. Ne var ki, Güvenlik Konseyi'ndeki oy usulünde büyük devletlere tanınmış olan imtiyazlı durum, veto hakkı çok fazla suiistimale uğramıştır. Zaman içerisinde Sovyet Rusya hariç diğer ülkeler veto hakkının kullanımının sınırlandırılması için birçok girişimde bulunmuş ancak bir netice elde edilememiştir (Çubukgil, 1950, s. 190). Nitekim BM’nin barışı ve güvenliği sağlamada başarılı olmadığına yönelik eleştiriler BM Güvenlik Konseyi'nin yapısına ve beş daimi üyenin veto yetkisine dairdir.

Dünyanın bugünkü sisteminin de BM'nin kurulduğu 1945 yılından çok farklı olduğu meydandadır. Bundan dolayı günümüzde Güvenlik Konseyi'nin dünyadaki güç dengesini yansıtmadığ1 ve beş daimi üyenin veto yetkisi nedeniyle BM'nin dünya sorunlarını çözemediği eleştirileri söz konusudur. Güvenlik Konseyi'nin var olan yapısal ve temsil sorunlarının günümüz dünyasında (Libya, Suriye, Filistin, Rohingya vs.) ve yakın tarihte yaşanan insani krizlere ve hatta soykırımlara (Bosna ve Ruanda) çözümler üretememiş olması birçok ülke tarafından işleyişinin sorgulanmasına yol açmıştır. Ayrıca Güvenlik Konseyi'nin yapısı 
gereği veto hakkı bulunan sayılı daimi üyelerin kendi ülkelerinin ulusal çıkarları doğrultusunda hareket etmeleri BM'nin temel hedefi dünya barışı ve güvenliğini oluşturma anlayışıyla da çelişki arz etmektedir (M. Erkut Ayvaz, 2019, s. 24, 25). Böylece uluslararası dengelerin değişmesi etrafinda sorumluluklarını etkin şekilde yerine getirmediği gerekçesi ile Güvenlik Konseyi’nin meşruiyeti sorgulanmaya başlamış ve neticede Güvenlik Konseyi üzerine çeşitli çevrelerden reform baskıları yapılmaya başlanmıştır. Güvenlik Konseyi'nin reformuna dair birtakım adımlar atılsa ve projeler oluşturulsa da bunların hiçbiri hayata geçirilememiş ve konseyin güncel gelişmelere ve sorunlara paralel olarak kendini reforme etmesi mümkün olmamıştır. Uluslararası güvenlik için oldukça önemli bir yapıyı temsil eden Güvenlik Konseyi bu nedenle üzerinde çokça tartışmanın yapıldığı sorunlu bir organ haline gelmiştir (Gölçek, 2019, s. 467).

\section{Extended Abstract}

The Second World War, which started with Germany's attack on Poland on September 1, 1939, continued for six years and ended with the surrender of Germany in May 1945 and Japan in August 1945. After the surrender of Germany, the Allies agreed to convene a conference in San Francisco to bring a new peace order to the world.

The great powers, who came together to form a new international system, took into account the failure of the League of Nations, which was established after the First World War, to protect and maintain world security and peace. The alliance system in the League of Nations prevented the effective use of the society's ability to represent and sanction, so a new mass war occurred. This is mass war; It was formed when the members of the League of Nations "Germany, Italy and Japan" took the aggressor side. With the transfer of the experiences, the United Nations has determined who will have the authority and responsibility in the preservation of peace and security. The war winners working on this bill held a conference in San Francisco to compile the constitution of the international organization. On the one hand, the great powers of the war (the United States of America, Britain and Soviet Russia) were trying to bring the Axis to their knees. On the other hand, they agreed on the establishment of an international organization "based on the equal sovereign rights of all peaceful nations and open to all nations (big and small) as soon as possible.

Dumbarton Oaks Draft, which forms the basis of the San Francisco Conference to which the UN Organization was signed, was prepared by the USA, Britain, Soviet Russia and the Republic of China. The UN was originally established in Dumbarton Oaks and later in Yalta. In this context, the San Francisco Conference served to fulfill the formalities rather than the basic principles of international relations. Because the great powers were able to defeat the attackers by using all kinds of resources in a long-lasting world war; they also have made an "ideal unity" which show their faith that their togetherness and cooperation will continue in order to prevent a new war. Thus, the Allies have revealed that they will achieve the security of all nations of the world with a concept of absolute "solidarity and understanding among themselves" by assuming certain duties and responsibilities in the name of the future of "world peace" within the new international organization to be named the UN. In this context, they had the right of veto, which they described in proportion to the duties and responsibilities they assumed. With the new system, "any state that wants to pursue a policy of aggression" will know in advance that it will find the world's "leading great powers in terms of resources and power" against itself. Therefore, with this reality, the "aggressor" will cease to venture into adventure. Even if aggression occurs, this time the Security Council with a certain number of members will decide on the situation and will be able to prevent the attack. However, "absolute unity and togetherness" of great powers is essential for this. Thus, taking a unanimous decision in any case gives "the great powers a definite advantage within the UN". A binding decision from the UN is only possible if "USA, Britain, Soviet Russia, Republic of China and France" did not use their veto right. The Turkish press, based on the evaluations that the veto right granted to the great powers, tied the future peace to a very weak thread; did not hesitate to express the missing and flawed aspects of the great powers' veto rights. The veto right granted to the great powers can be considered as an indication that the UN is not a democratic institution. Besides, with this feature, the organization loses its universality. This structure of the UN Organization, which recognizes the equality of nations as the highest principle, is in contrast to the ideal it wants to realize. The Turkish press will also criticize the "big and small state 
difference" being taken into account in the UN structure through the veto system. Because "to emphasize" that sacrifice was shown only by great powers during the war; and the fact that decisions will be taken by joining the votes of the big five on every important issue reduces the importance of other member "small countries" to nothing. The UN values the votes of each of the five big states, while disregarding the medium and small nations fighting over their power during the war, because it keeps "the small small and the big big".

As a result, the veto right, which gives a definite superiority to the great states, reveals the incomplete and flawed structure of the UN. Since its establishment, Turkey who acts with the ideal of "peace at home, peace in the world" became a member of the UN Organization in order to take its place in an international organization with its attitude in favor of peace and stability. In this respect, the Turkish government, which accepted the United Nations Organization Constitution despite its deficiencies; has also declared that "it will not exist in an irregular, unstable and insecure environment". At the same time in this period, Turkey who was facing with the threat of "March-June 1945 The Soviet Notes" also pleased that the USA has taken a leading role in world peace and security and gave up the "policy of isolation". Turkey in the face of Soviet Russia; has tried to find allies for himself. And during the war, Turkey took a stand with its ally Britain and then the USA, which advocated democracy at every opportunity and adapted to changing political conditions. This situation emerges as one of the first signs of the Bipolar political structure that will be established in the international system after the Second World War.

Keywords: United Nations, Security Council, Veto, Great States.

\section{Kaynakça \\ Resmi Yayınlar}

HC (House of Commons) Deb (Debate) 22 August 1945 (The Full Date) vol (volume) 413 c. (Column) 659.

HC Deb 22 August 1945 vol 413 c661.

HC Deb 22 August 1945 vol 413 c707

HC Deb 22 August 1945 vol 413 c727

TBMM Zabit Ceridesi, 7. Dönem, 19. Cilt, 90. Birleşim, 15.08.1945.

\section{Süreli Yayınlar}

Akşam

Cumhuriyet

İkdam

Son Posta

Tan

The Times

Ulus

Vatan

Yeni Sabah

\section{Süreli Yayın Makaleleri}

(10 Nisan 1945). "Başlica Dikkat Noktası". İkdam.

(16 Nisan 1945). "Ruzveltin Vasiyeti". Yeni Sabah.

(2 Nisan 1945). "San Francisco Konferans1". Tasvir.

(26 Nisan 1945). "Açış Nutku ve Hedef”. İkdam.

(27 Nisan 1945). "Daha İyi Bir Dünya İçin”. Yeni Sabah.

(9 Nisan 1945). "Önemli Bir Nutuk: Amerika'nın Sulh Siyasetinin Esası, Küçük Milletlerin İstiklalidir". Vatan.

Atay, F. R. (2 Nisan 1945). "Konferans Etrafinda Söylentiler". Ulus.

Belge, B. (28 Nisan 1945). "Hava Rüzgârlı". Tanin.

Benice, E. İ. (22 Haziran 1945). "Dünyanın Emniyeti”. Son Telgraf.

Benice, E. İ. (24 Nisan 1945). "Davanin Hassas Noktası”. Son Telgraf.

Benice, E. İ. (26 Nisan 1945). "Konferans Açıldı!". Son Telgraf.

Benice, E. İ. (27 Nisan 1945). "Sulh mu, Emniyet mi Daha Önce!". Son Telgraf. 
Fenik, M. F. (12 Nisan 1945). "Küçük Devletlerin Haklarr". Ulus.

Fenik, M. F. (8 Nisan 1945). "Küçük Devletlerin Hakları". Ulus.

Nadi, N. (12 Nisan 1945). "Büyük Kim Küçük Kim?”. Cumburiyet.

Nadi, N. (26 Nisan 1945). "San Francisco Konferans1 Açllırken”. Cumburiyet.

Nadi, N. (3 Nisan 1945). "San Francisco Konferansı Geri Kalırsa". Cumburiyet.

Sadak, N. (23 Nisan 1945). "Sulh ve Emniyet Pamuk İpliğine Bile Bağlanmıor". Akşam.

Sadak, N. (25 Nisan 1945). "Harpte Birleşenler Arasında İlk Sulh ve İyi Niyet Denemesi”. Aksam.

Sadak, N. (27 Nisan 1945). "M. Truman'ın Cesaretli Nutku Konferansa İlham Kaynağı Olmalıdır". Aksam.

Sadak, N. (28 Haziran 1945). “Amerika'dan Yükselen Ahlak, Adalet, Hürriyet Sesi”. Akesam.

Sertel, M. Z. (25 Nisan 1945). "San Francisco Konferansi Ne Yapacak?”. Tan.

Sertel, M. Z. (27 Nisan 1945). “Türk Gazeteleri Neden Bu Kadar Kötümserdir?”. Tan.

Sertel, M. Z. (4 Nisan 1945). "San-Francisco Konferansi Etrafinda Dedikodular”. Tan.

Sertel, M. Z. (5 Mayıs 1945). "Konferansta Türk Tezi”. Tan.

Sertel, M. Z. (6 Nisan 1945). "San Francisco Konferansı ve Londra Basını". Tan.

Sertel, M. Z. (7 Nisan 1945). "San Francisco Konferansı ve Türkiye" . Tan.

Tekeli, E. (6 Mayıs 1945). "Konferansta Türk Tezi”. Ulus.

Tekeli, E. (15 Mayıs 1945). “Türk Tezi Üzerinde Açılamalar, Ulus.

Turan, K. (22 Nisan 1945). "Barış İçin Dilek ve Emekler". Ulus.

Uşaklıgil, E. (1 Nisan 1945). "San Francisco Yolunda Işıklar...”. Son Posta.

Yalçın, H. Y. (1 Nisan 1945). "Arslan Payı". Tanin.

Yalman, A. E. (3 Nisan 1945). "Dünyanın Ana Davası 1: San Francisco Konferansı'nın Arifesinde Ahenksizlik İstidatlar". Vatan.

Yalman, A. E. (6 Nisan 1945). "Karşılıklı Anlayış ve Sayg1". Vatan.

\section{Kitap ve Makaleler}

Armaoğlu, F. (2016). 20. Yü̈yzl Siyasi Taribi. İstanbul: Timaş.

Ayvaz, M. Erkut. (Eylül 2019). BMGK Reformu Almanya Ve Türkiye'nin Karşılaştırmalı Pozisyonları,

Siyaset, Ekonomi Ve Toplum Araştırmaları Vakfi (SETA), S. 295. Erişim Adresi: https://setav.org/assets/uploads/2019/09/A295Tr.pdf. Erişim Tarihi: 05.06.2021.

Barlas, D. (2017). Milletler Cemiyeti'nde Türkiye: İyimserlik ve Kuşku Arasında. Uluslararası İliskkiler, C.14, S. 55, 93-111. Erişim Adresi: http://home.ku.edu.tr/ dbarlas/uid.pdf.

Başarır, M. (2019). Sovyet Rusya'nın 1925 Dostluk ve Tarafsızlık Antlaşması'nın Feshine Yönelik Türkiye'ye Verdiği Notaların Türk Basınına Yansıması. Belgi Dergisi, C.2, S.18, 1417-1448. doi:10.33431/belgi.523548.

Çubukgil, M. (1950). Birleşmiş Milletler Teşkilâtında Veto. Ankara Üniversitesi Hukuk Fakültesi Dergisi, 7 , 174-191. Erişim Adresi: http://dergiler.ankara.edu.tr/dergiler/38/248/2273.pdf

Gölçek, Ş. G. (2019). Birleşmiş Milletler Güvenlik Konseyi'nin Reform Sorunsalı. Ömer Halisdemir Üniversitesi İktisadi ve İdari Bilimler Fakültesi Dergisi, 12(4), 466-477. doi: 10.25287/ohuiibf.512311

Kıran, A. (2008). Milletler Cemiyeti ve Önlenemeyen Savaş. Girne American University Journal of Social and Applied Sciences, 3 (6), 19-36. ErişimAdresi:https://www.researchgate.net/profile/Abdullah_Kiran2/publication/265476695_Milletler_ Cemiyeti_ve_Onlenemeyen_Savas/links/5c63f1cf92851c48a9d026b0/Milletler-Cemiyeti-ve

Oenlenemeyen-Savas.pdf.

Kutlu, İ. (2018). Birleşmiş Milletler Güvenlik Konseyi'nde Reform Tartışmaları. Bilge Strateji, C.10, S. 19, 177-200. Erişim Adresi: https://dergipark.org.tr/tr/download/article-file/678027.

Öztekin, H. (2016). Tan: Serteller Yönetiminde Mubalif Bir Gazete. İstanbul: Tarih Vakfi Yurt Yayınları.

Polat, Doğan Ş. (2020). Kuruluşundan Çöküşüne Milletler Cemiyeti Sistemi. Elektronik Sosyal Bilimler Dergisi, 19(76), 1950-1967. doi:10.17755/esosder.677815.

Sander, O. (2016). Siyasi Tarih 1918-1994. Ankara: İmge Kitapevi. 